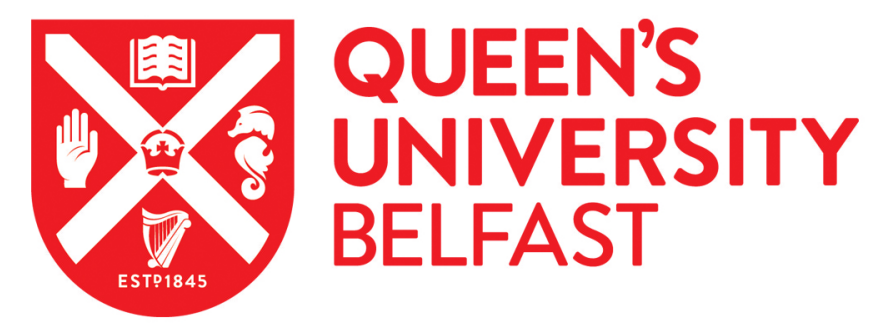

\title{
Judicial Impartiality and Independence in Divided Societies: An Empirical Analysis of the Constitutional Court of Bosnia-Herzegovina
}

Schwartz, A., \& Murchison, M. J. (2016). Judicial Impartiality and Independence in Divided Societies: An Empirical Analysis of the Constitutional Court of Bosnia-Herzegovina. Law \& Society Review, $50(4), 821-855$. https://doi.org/10.1111/lasr.12237

Published in:

Law \& Society Review

Document Version:

Peer reviewed version

Queen's University Belfast - Research Portal:

Link to publication record in Queen's University Belfast Research Portal

Publisher rights

Copyright Wiley 2016.

This is the peer reviewed version of this article, which has been published in final form at DOI: 10.1111/lasr.12237 . This article may be used for non-commercial purposes in accordance with Wiley Terms and Conditions for Self-Archiving.

\section{General rights}

Copyright for the publications made accessible via the Queen's University Belfast Research Portal is retained by the author(s) and / or other copyright owners and it is a condition of accessing these publications that users recognise and abide by the legal requirements associated with these rights.

Take down policy

The Research Portal is Queen's institutional repository that provides access to Queen's research output. Every effort has been made to ensure that content in the Research Portal does not infringe any person's rights, or applicable UK laws. If you discover content in the Research Portal that you believe breaches copyright or violates any law, please contact openaccess@qub.ac.uk. 


\title{
Judicial Independence and Impartiality in Divided Societies: An Empirical Analysis of the Constitutional Court of Bosnia- Herzegovina
}

\author{
Alex Schwartz \\ School of Law \\ Queen's University Belfast \\ a.schwartz@qub.ac.uk \\ Melanie Murchison \\ Department of Sociology \\ Center for Law, Society and Justice \\ University of Wisconsin-Madison \\ mmurchison@wisc.edu
}

June 2016

\section{Introduction}

The challenge of designing institutions to manage ethno-national conflict is a long-running topic of academic inquiry and dispute (see Lijphart 1977; Horowitz 1985; McGarry \& O'Leary 2007). Generally speaking, the focus is on how legislatures, executives and electoral systems can be organized to accommodate the politics of deeply divided societies (Choudhry 2008). The design of courts figures much less frequently in this literature (for some exceptions, see Choudhry \& Stacey 2012; Horowitz 2006; Issacharoff 2015; and McCrudden \& O’Leary 2013). But courts, particularly constitutional courts, may play a vital role in such contexts. Although inter-group trust is likely to be fragile in the wake of conflict, courts may help to make constitutional commitments to group autonomy and the protection of minority Research for this article was facilitated by a British Academy-Leverhulme grant. We presented earlier versions of our findings at annual meetings of the American Political Science Association (2014, Washington D.C.) and the International Political Science Association (2014, Montreal). We thank Ganimete Asllani-Price for her research assistance and Damir Banović, David Feldman, Nedim Kulenović, Joseph Marko, Christopher McCrudden, Brendan O'Leary, and Zoran Oklopcic for their helpful comments and insight. We owe a special debt of gratitude to Christopher Raymond for his very generous advice and constructive criticism. We also thank the anonymous reviewers for helping us to improve the analysis considerably. Any errors are entirely our own. Please direct all correspondence to Alex Schwartz, School of Law, Queen's University Belfast, 28 University Square, Belfast, Northern Ireland BT7 1NN (email: a.schwartz@qub.ac.uk) 
rights more credible than they might otherwise be (see Lake \& Rothchild 1996; and North \& Weingast 1989). Furthermore, any constitutional settlement of any complexity will inevitably generate disputes about the meaning and implication of its terms. Where disagreement cannot be resolved politically, a constitutional court offers a potential focal point to coordinate a solution and, hopefully, avoid constitutional collapse (see Elkins, Ginsburg \& Melton 2009:107-8; and Ginsburg 2012:725). Both of these functions require the court to be, or at least appear to be, sufficiently impartial and independent with respect to rival ethno-political factions.

Although judicial impartiality and independence are often conflated (see Karlan 1999; and Tiede 2006), the two can be usefully distinguished. We can define "judicial impartiality" as the extent to which judges are unmoved by prejudices or ideological biases that might incline them to decide a dispute one way or the other. In contrast, "judicial independence" can be defined as the extent to which judges are insulated from threats and incentives that might motivate them to decide a dispute one way or the other (regardless of the legal merits and their own sincere preferences). Each of these qualities is associated with a distinct aspect of court design. As Brinks and Blass (2016) explain, the design of courts varies with respect to what they call "ex ante autonomy" and "ex post autonomy". The former concerns the scope for political actors to influence the political biases of the court through the appointment of "ideological allies" (Brinks \& Blass 2013: 5) and therefore affects judicial impartiality. The latter concerns the extent to which political or other external actors can pressure judges to decide a case one way or the other and therefore goes to judicial independence.

Neither the impartiality nor the independence of constitutional courts can be taken for granted. Even in relatively homogenous democracies, constitutional courts are often seen to be highly politicised in terms of their appointment processes, decision-making, and the kinds of cases they hear (Garoupa, Gomez-Pomar, \& Grembi 2013; Amaral-Garcia, Garoupa, \& 
Grembi 2009; and Hönnige 2009). But courts in deeply divided polities face special dangers and challenges, particularly in the wake of conflict where the rule of law is weak (Haggard \& Tiede 2014). Minorities may worry that the court will be indefinitely captured by the majority and, consequently, have little or no confidence in the court's ability to protect their rights and interests (Sadurski 2014: 304-328). Furthermore, assuming that dissenting opinions are made public, conspicuous ethnic or ethno-national divisions within the court may undermine its image as a neutral arbiter of constitutional dispute (Garoupa \& Ginsburg 2011). Thus, to the extent that it might affect judicial impartiality and independence, the design of a constitutional court in a deeply divided society may be nearly as important to the success of a constitutional settlement as the substance of the settlement itself. Indeed, the conventional wisdom, in both academic and policy circles, is that the design of courts does make a difference. Merit-based selection systems are favoured over party-political appointment processes on the grounds that they are more likely to select better qualified and more impartial judges (see Garoupa \& Ginsburg 2009; Volcansek 2007; and Reddick 2001). Life or long-term tenure is thought to enhance judicial independence by insulating judges from careerist pressures and incentives to placate political elites (see La Porta et al. 2004; Jackson 2007). These suppositions have recently been subjected to some rigorous comparative research (Hayo \& Voigt 2007; and Melton \& Ginsburg 2014), ${ }^{1}$ but the challenge of achieving judicial impartiality and independence in ethnically or ethno-nationally divided polities remains virtually uncharted research territory.

With reference to the experience of the Constitutional Court of Bosnia-Herzegovina, we investigate the relationship between ethno-national affiliation and judicial behaviour and

\footnotetext{
${ }^{1}$ As we discuss below, the results of this research are mixed with respect to how and to what extent the design of courts affects judicial behaviour.
} 
the extent to which variation in judicial tenure amplifies or dampens that relationship. ${ }^{2}$ The Bosnian Constitutional Court is a particularly interesting case-study for several reasons. Firstly, it provides a window into the challenges facing recently empowered courts in transitional and post-conflict settings. The study of courts in contexts where the rule of law is relatively tenuous may help illuminate the factors that determine how and why some courts become "consequential" while others remain marginal or ineffectual (see Epstein et al 2001; and Kapiszewksi et al 2013). Second, the case of a court in an ethno-nationally divided society provides an opportunity to see if and how the "attitudinal model" of judicial behaviour (which has been so influential in the study of courts in the United States) can be extended to contexts where the more familiar left-right ideological spectrum is usually overshadowed by other kinds of politics. Such efforts are vital if we are to move beyond well-worn theoretical frameworks that have relied, perhaps too heavily, on courts in the United States for their inspiration (see Hirschl 2014: ch 5). Finally, the record of the Bosnian

${ }^{2}$ Our approach assumes, as countless other studies do, that quantitative analysis allows for valid causal inference about the factors that affect judicial behaviour. However, we recognise that some would argue that ethno-national background, in so far as it is an immutable personal characteristic akin to race or sex, cannot be treated as a true causal variable because it cannot be conceptualised as a "treatment", i.e. a property that is, at least hypothetically, amenable to "manipulation" (see Boyd et al 2010; Greiner and Rubin 2011). This interpretation of causal inference is not accepted by everyone (see Sen \& Wasow 2014; and Marcellesi 2013). We are agnostic about the right way to conceptualise variables of this kind but, for the sake of convenience, the discussion that follows sometimes refers to the "influence" or "effect" of ethno-national affiliation on judicial behaviour. The reader may elect to interpret such statements as propositions about "relationships" between variables (as opposed to true "causal effects"). 
Constitutional Court is particularly fertile ground for investigating the effects of court design. In the absence of "mid-stream" changes to the basic institutional makeup of courts, studies that seek to test hypotheses about the effects of court design rely on cross-national or crossjurisdictional comparisons for variance (Brace \& Hall 1997: 1210). In contrast, the Bosnian Constitutional Court allows for a kind of within-country natural experiment. Although the Court has always been composed of an equal number of politically appointed judges from each of the three main communities (two Bosniaks, two Serbs, and two Croats), the first set of judges were appointed for five-year non-renewable mandates while judges appointed thereafter enjoy long-term tenure (with mandatory retirement at age seventy). We aim to leverage this "mid-stream" institutional change to estimate the effects of judicial tenure on judicial behaviour.

Based on a statistical analysis of an original dataset of the non-unanimous abstract review decisions of the Constitutional Court, we find that judges on the Constitutional Court do in fact divide predictably along ethno-national lines and that these divisions cannot be reduced to a residual loyalty to their appointing political parties. Contrary to some theoretical expectations, however, we find that long-term tenure does not dampen the influence of ethnonational affiliation on judicial behaviour. Moreover, our findings suggest that the longer a judge serves on the Court the more ethno-national affiliation seems to influence her decisionmaking. We conclude by considering how alternative arrangements for the selection and tenure of judges might help to ameliorate this problem.

\section{Background on Bosnia-Herzegovina and the Constitutional Court}

In 1995, representatives of the belligerent parties to the Bosnian war concluded the so-called "Dayton Agreement", ending a conflict that had already claimed about 100,000 lives. Annex 
4 to the Dayton Agreement included a new constitution for Bosnia-Herzegovina, prescribing a complex mix of power-sharing and territorial decentralization as a compromise between the Bosniak (Bosnian Muslim) goal of a unitary sovereign state and the Croat and Serb objectives of separate/irredentist breakaway republics (Keil 2014; Bieber 2006). Pursuant to the Agreement, the former Yugoslav Republic of Bosnia-Herzegovina was divided into two substate entities, the Federation of Bosnia-Herzegovina ("FBiH"), which is mostly Bosniak and partially Croat and is itself divided into ten cantons, and the Serb-dominated Republika Srpska (hereafter "RS"). ${ }^{3}$

Alongside territorial decentralization, the Constitution fragments power within the central state-level (hereafter "BiH") institutions, requiring power-sharing between the three "constituent peoples". 4 The executive is to be led by a three person presidency with positions allocated along ethno-national lines, i.e. one Bosniak, one Serb, and one Croat. ${ }^{5}$ The Bosniak and Croat members of the Presidency are elected by voters registered to vote in the $\mathrm{FBiH}$ who may vote for either the Bosniak or Croat member of the Presidency but not for both, while the Serb member of the Presidency is directly elected by voters registered to vote in RS. Executive power is parcelled out among a Council of Ministers, 1/3 of which must be

\footnotetext{
${ }^{3}$ Following an arbitration process to settle a territorial dispute that was not yet resolved at the time of the Agreement, a distinct administrative district, Brčko, was later formed and initially administered by the international community. Although Brčko is formally part of both substate entities, it is now administered by its own municipal government and subject to the laws of the central state.

${ }^{4}$ The phrase "constituent people" is introduced in the Constitution's preamble and used throughout the Constitution to refer to Bosniaks, Serbs, and Croats.

${ }^{5}$ Art. V.
} 
appointed from the territory of $\mathrm{RS}^{6}{ }^{6}$ These power-sharing mechanisms are complemented by a set of mutual veto powers (Bahtić-Kunrath, 2011). ${ }^{7}$ All of this is overseen by the peculiar institution of the Office of the High Representative, effectively an extension of the "international community" empowered to supervise and support the implementation and maintenance of the Dayton Agreement (see Belloni 2008; and Caplan: 2004). ${ }^{8}$

To uphold the legal dimensions of these arrangements, the Constitution establishes an apex court: the Constitutional Court of Bosnia and Herzegovina. ${ }^{9}$ The Constitutional Court [hereafter "the Court"] is a variation on the "Kelsenian" model common throughout much of continental Europe (Stone 1990). Consistent with that model, the Court has exclusive "abstract review" jurisdiction to hear disputes arising under the Constitution "between the Entities or between Bosnia and Herzegovina and an Entity or Entities, or between institutions of Bosnia and Herzegovina". ${ }^{10}$ Such disputes may only be referred to the Court by "a member

\footnotetext{
${ }^{6}$ Art. V, 4(b); Art. 4, 3(e).

${ }^{7}$ Art. 5, 2(d). There effectively two veto powers: (1) the "vital national interest" veto, which may be activated either by a member of the Presidency or a majority of the ethnic caucus in the House of Peoples; and (2) the so-called "entity veto", whereby all decisions in both houses require support of at least one-third of the delegates elected from each sub-state entity. ${ }^{8}$ Although the Office of the High Representative has played a somewhat less interventionist role in Bosnian politics in recent years, the country has yet to meet the conditions required for phasing the institution out.
}

${ }^{9}$ Art. VI. The Court is technically a reconstituted version of the original sub-national Constitutional Court of the Socialist Republic of Bosnia and Herzegovina (a constituent republic of what was Yugoslavia).

${ }^{10}$ Art. VI 3(a). 
of the Presidency, by the Chair of the Council of Ministers, by the Chair or a Deputy Chair of either chamber of the Parliamentary Assembly, by one-fourth of the members of either chamber of the Parliamentary Assembly, or by one-fourth of either chamber of a legislature of an Entity". ${ }^{11}$ Provided that the petitioner falls within one of these categories, the Court has no discretion to refuse to hear an abstract review challenge. In addition, the Court has appellate jurisdiction "over issues under this Constitution arising out of a judgment of any other court in Bosnia and Herzegovina". ${ }^{12}$ Lower courts may also refer a law to the Constitutional Court where its decision depends on the law's validity. ${ }^{13}$ Finally, in exceptional cases, the Court has jurisdiction to review the use of the so-called "vital national interest" veto where legislative deadlock cannot otherwise be resolved. ${ }^{14}$

The constitutional provisions governing the appointment of judges to the Constitutional Court reflect the system of ethno-territorial power-sharing in BosniaHerzegovina: four judges are appointed by the legislature of the $\mathrm{FBiH}$ entity and two by the legislature of the RS entity. ${ }^{15}$ In addition to these "domestic" judges, the Constitution also provides for the inclusion of three "international" judges, ostensibly as an impartial ballast, to be appointed by the President of the European Court of Human Rights in consultation with

11 Ibid.

${ }^{12}$ Art. VI 3(b). In practice, the Court's appellate jurisdiction is much broader than might be supposed because the right to a fair hearing in civil and criminal matters, protected under Art. 3(e), may be engaged by virtually any legal proceeding where it is alleged that an error was made by a lower court.

\footnotetext{
${ }^{13}$ Art. VI 3(c).

${ }^{14}$ Art. IV 3(f).

${ }^{15}$ Art. VI 1(a).
} 
the Presidency of BiH. ${ }^{16}$ These judges cannot be from Bosnia-Herzegovina or from any of its neighbouring countries. ${ }^{17}$ The only limit imposed by the Constitution on the selection of the domestic judges is the somewhat vague criterion that they be "distinguished jurists of high moral standing". ${ }^{18}$ Hence, the judges come to the Court with varied professional backgrounds and experience (see the 'Appendix'). ${ }^{19}$ Eight of the eighteen domestic judges who have sat on the Court were previously judges on lower courts and/or entity-level constitutional courts. Five of those eighteen were previously legal academics, holding positions at law schools in Sarajevo, Banja Luka, or Mostar. Seven held some kind of government job or elected political office prior to being appointed to the Constitutional Court. All of the domestic judges are either graduates of Bosnian law schools (i.e. Banja Luka, Mostar, or Sarajevo) or law schools in the former Yugoslavia (i.e. Belgrade or Novi Sad). There are clear ethno-territorial patterns in these various backgrounds. Of those judges with prior judicial experience, Bosniak and Croat judges served on courts in $\mathrm{FBiH}$ (or what is now $\mathrm{FBiH}$ ) while the Serb judges served on courts in RS (or what is now RS). Similarly, of those judges with prior political or government experience, Bosniaks and Croats occupied such roles within $\mathrm{FBiH}$ entity (or what is now $\mathrm{FBiH}$ ), while the Serbs had roles within RS (or what is now RS). The judges' legal education also appears to follow an ethno-territorial pattern: most of the Bosniak or Croat judges went to law school in what is now $\mathrm{FBiH}$, while all of the Serb judges trained in what is now either the RS entity or Serbia.

Although there is no legal requirement that the domestic judges be of any particular
${ }^{16}$ Art. VI 1(a).
${ }^{17}$ Art. VI 1(b).
${ }^{18}$ Art. VI 1(b).
${ }^{19}$ Our biographical data on the judges is taken from the Court's public records. 
ethno-national background, the convention is that the four judges appointed by the $\mathrm{FBiH}$ entity legislature will always include two Bosniaks and two Croats and the two judges appointed by the Serb entity legislature will be Serbs. By all accounts, the appointment of these judges is closely orchestrated by the political parties (Radić-Dragić 2014). When a vacancy in one of the domestic posts arises, a commission for selection and appointment is constituted within the relevant legislature to invite and review applications and compile a list of candidates. This list is then presented to the legislature to elect the requisite number of judges by secret ballot. At the FBiH entity legislature, the process is subject to a kind of elite pact; the dominant Bosniak and Croat parties separately determine which of "their" respective judges will be nominated and ultimately appointed. At the RS entity legislature, the process is simpler - appointments are controlled by the dominant party (which has always been a Serb nationalist party).

Despite the political nature of the appointment process, the Court enjoys a good deal of formal "ex post autonomy". Once appointed, the judges may only be removed "for cause by consensus of the other judges". ${ }^{20}$ Otherwise, as was mentioned earlier, the first set of ${ }^{20}$ Art. VI 1(c). This power has only been used once, in 2010, after leaked correspondence between Judge Krstan Simić and Serb politicians seemed to show the existence of on-going ties (and even active collusion) between Simić and SNSD. The Court acted quickly to oust Simić, justifying his removal on the grounds that he had been "deliberately undermining the reputation and dignity of the Constitutional Court of Bosnia and Herzegovina and dignity of a judge" (see the Court's decision at http://www.ccbh.ba/public/down/Decision_on_Dismissal.pdf). It should also be noted that, despite questionable constitutional authority, the High Representative once acted to block the appointment of two Serb judges (see "Decision annulling the appointment of two Judges from the RS to the BiH Constitutional Court", 16 September 2002). 
judges held short-term mandates of five years while all judges thereafter are appointed for long-term mandates with mandatory retirement at age seventy. ${ }^{21}$ Furthermore, the Court has complete control over its own internal rules and procedures, which are neither prescribed by the Constitution nor defined by legislation, ${ }^{22}$ and it is also responsible for drafting its own budget (to be allocated from a central state fund). ${ }^{23}$

In addition to the formal independence enjoyed by the Court, the fragmented and decentralized political system in Bosnia-Herzegovina (with its several veto points) makes it difficult for domestic political actors to coordinate and launch a direct attack against it (Ferejohn 2002; Tsebelis 2002). Consequently, the Court is comparatively insulated from overt "court curbing". ${ }^{24}$ Indeed, contrary to the expectation that constitutional courts in new

${ }^{21}$ Art. VI 1(c). We have not been able to conclusively determine the original rationale for this two-phased tenure system, but it is said to have been a compromise between the preferences of the Dayton Agreement's negotiators.

${ }^{22}$ See Article VI.3(a), which empowers the Court to adopt its own rules.

${ }^{23}$ Art. III, Rules of the Constitutional Court of Bosnia and Herzegovina (Official Gazette of BiH no. 22/14). The Court defended its financial independence in Case U 6/06 (29 March 2008). The Court invalidated a national law that sought to reduce the salaries of the judiciary, reasoning that the Constitution requires that the Court itself control the plan and allocation of its own budget.

${ }^{24}$ It should be noted, however, that the High Representative's extraordinary powers to legislate by decree have been used on one occasion to effectively overrule a decision of the Court (see Everly: 2008). The relationship between the Office of the High Representative and the Court is a fascinating topic in its own right but it is also one that is beyond the scope of the discussion here. 
democracies will be relatively timid and underutilized (Ginsburg 2004), the Court was quickly drawn into the political fray and asserted itself as a powerful and important player in several early landmark cases. ${ }^{25}$ The best example of this confidence is Case U-5/98 (often called "The Decision on the Constituency of Peoples"), where the Court invalidated sections of both entity constitutions. The case arose from an abstract review challenge brought by Alija Izetbegović, then the Bosniak member of the $\mathrm{BiH}$ state-level Presidency. The main thrust of the challenge concerned several provisions of the entity constitutions which, in the case of RS, seemed to reflect a mono-national and distinctly Serb-centric conception of the sub-state entity, or, in the case of the $\mathrm{FBiH}$ entity, granted special recognition and rights to Bosniaks and Croats but failed to include Serbs on equal footing. Although nothing in the substantive body of the Constitution explicitly prohibited any of this, the petitioner argued that the challenged provisions of the entity constitutions contravened an overarching constitutional principle, referenced in the Constitution's Preamble, guaranteeing the collective equality of Bosniaks, Croats and Serbs, as "constituent peoples". The majority of the Court agreed with the core of this argument and invalidated several of the challenged provisions in both entity constitutions.

The majority's decision was bold for two reasons. First of all, it favoured an abstract teleological theory of the Constitution, only vaguely supported by the language of the Preamble, against the more concrete historical claim (favoured by the dissent) that the sub-

${ }^{25}$ In its first few years, the Court was called on to decide controversies of profound constitutional significance: the constitutionality of the Dayton Agreement itself (Case U7/97); changes to the organization of the Council of Ministers (Case U-1/99); the amenability of the High Representative's decisions to judicial review (Case U-9/00); and, perhaps most controversially of all, the compatibility of provisions of the entity constitutions with the constitutional principle of the "equality of constituent peoples" (Case U-5/98). 
state entities were deliberately designed as bases for the self-government of different constituent peoples (see Marko 2005: 10-11; and Kulenović 2016). Second, overruling important sections of the entity constitutions would inevitably generate disagreement and uncertainty about the amendments needed to implement the Court's decision. As it happened, no agreement among the political parties on the requisite amendments was forthcoming and so a range of changes were ultimately imposed by the Office of the High Representative in 2002, expanding power-sharing to all levels of government and requiring that all three constituent peoples within both entities be accorded the same status and rights (Bieber 2006:121-33).

Case U-5/98 is a complicated and difficult read, particularly because it is divided into several "partial decisions". Nevertheless, one blunt fact is apparent: the Court divided along clear ethno-national lines: a majority bloc of Bosniak judges and International judges lined up against a vociferous dissenting bloc of Serb and Croat judges to invalidate sections of both the FBiH and RS constitutions. Split decisions such as this are not likely to escape notice in a deeply divided society. Indeed, although it may have helped assuage fears that the Court would be captured by one community to the detriment of the others, the practice of including a set number of judges from each constituent people also serves to draw attention to the ethno-national affiliation of the judges, inviting accusations of political bias in nonunanimous and politically sensitive cases. Such accusations extend beyond the national judges (who are simply presumed to favour their putative communal interests) to the international judges as well, who are thought to favour the interests of the "international community" (Feldman 2011: 219). Indeed, academic commentary, although less vitriolic in tone, concurs with the general impression that the Court is, or at least has been, prone to ethno-nationally driven decision-making patterns (McCrudden \& O'Leary 2013: ch. 6).

The most recent case to highlight this problem is the Court's decision in Case U 3/13 
(November 2015), where a 5-4 majority of Bosniak and international judges ruled that a law establishing the 9th of January as a public holiday in the RS entity was unconstitutional. The 9th of January is significant because it marks the day in 1992 when Bosnian Serbs proclaimed the "independence" of Republika Srpska, in addition to being the day when Eastern Orthodox Serbs celebrate St. Stephen's Day. For this reason, the majority in U 3/13 concluded that the law unconstitutionally discriminated against non-Serbs. Prior to the decision, the RS legislature had issued a pre-emptive declaration stating that it would not obey the Court if it invalidated the law on public holidays (see EU Delegation to Bosnia and Herzegovina, Flash Report, 10 April 2015). It is no great surprise then that Bosnian Serb politicians have since refused to implement the Court's ruling and condemned the Bosniak judges for imposing their political preferences "with the help of foreign judges". ${ }^{26}$ Milorad Dodik, the President of the RS entity, went so far as to call the Court "nothing but a Muslim court against Serbs". ${ }^{27}$ At the time of writing, the main Bosnian Serb parties are threatening to blockade central institutions unless a new law is passed to remove international judges from the Court and prevent the possibility of one community's judges outvoting the other two communities' judges in split decisions. Beyond this recent controversy, the Court has had compliance problems with many of its decisions (EU Delegation to Bosnia and Herzegovina, Flash Report, 23 April 2015; see also Banovic et al 2014).

\section{Theory and Hypotheses}

\footnotetext{
${ }^{26} \mathrm{http}$ //www.balkaninsight.com/en/article/sds-proposing-changes-to-bosnian-constitutionalcourt-12-08-2015-1.

${ }^{27}$ http://www.balkaninsight.com/en/article/bosnian-serbs-defy-bosnian-constitutional-courtover-serb-national-day-ruling-11-27-2015.
} 


\section{The Influence of Ethno-National Affiliation on Judicial Behaviour}

The impression that the Constitutional Court divides along ethno-national lines is consistent with what one might expect in society such as Bosnia-Herzegovina. One of the characteristic traits of deeply divided societies is the tendency for the salient cleavages to infuse almost every aspect of social and political life. Elections proceed "like a census", with parties mobilizing on the basis of ethnic affiliation (Moore 2001: 89). Residence, education, media, and economic opportunity structures also tend to be fragmented along the same lines. In short, as Donald Horowitz puts it, "[i]n divided societies, ethnic affiliations are powerful, permeative, passionate, and pervasive" (1985: 12). Bosnia-Herzegovina certainly fits this pattern. All of the major political parties draw on a virtually mono-ethnic electoral base. Even the ostensibly non-nationalist and multi-ethnic Socijaldemokratska Partija BiH ("SDP") relies on an overwhelmingly Bosniak vote. Moreover, with the sole exception of the SDP, all of the major parties are overtly nationalist in their orientation and, for most of the post-war period, relatively hard-line nationalist parties have held the reins of power at both central and entity levels. Even the once ostensibly "moderate" Serb nationalist party, Savez nezavisnih ("SNSD") openly threaten secession and frequently contest the legitimacy of the central state institutions. In addition, as a result of massive population displacement during the war, the country is divided into mostly ethnically homogenous zones; mixed municipalities (such as Sarajevo, Mostar, or Brčko) are the exception (Bieber 2006:29-33). Predictably, education is also mostly mono-ethnic; even in mixed areas, separate Croat and Bosniak schools teaching different curricula sometimes operate under the same roof (Swimelar 2013). ${ }^{28}$ Likewise, media is ethnically differentiated, with Bosniaks oriented

\footnotetext{
${ }^{28}$ Recently, the FBiH Supreme Court ruled that this "two schools, one roof" practice was discriminatory (see Supreme Court of the Federation of BiH, Judgment 580 Ps 08565313
} $\operatorname{Rev}[29.08 .2014])$. 
towards Sarajevo-based outlets, Croats looking to media from Croatia, and Serbs consuming media from RS or Serbia (Jusic \& Ahmetašević 2013). Finally, and partly as a result of geographic segregation, economic status is ethnically stratified, with Croats being generally more affluent than Bosniaks and Serbs (Bieber 2006: 33-39).

Given the pervasive salience of ethno-national divisions in Bosnia-Herzegovina, there at least two theoretical reasons to expect ethno-national affiliation to influence judicial behaviour on the Court. Firstly, this is what a broad reading of the "attitudinal model" of judicial behaviour would predict. Proponents of the attitudinal model, pioneered to explain judicial decision-making on the United States Supreme Court, typically look at how individual judges' votes tend to fall along a left-right ideological spectrum (Segal \& Spaeth 2002). But there is no reason why the basic idea of the attitudinal model - that judges are influenced by their political preferences - cannot be extended to other kinds of politics (see Ostberg \& Wetstein 2007). If judges do decide many cases according to their political preferences, and those preferences are structured by ethno-national affiliation, then we should expect judicial behaviour to reflect differences in ethno-national affiliation. In the case of the Bosnian Constitutional Court, this expectation is buttressed by the fact that the appointment process is dominated by ethno-nationalist political parties who, in seeking to advance their political goals, can appoint judges' whose ethno-national politics mirror their own.

A second reason to expect ethno-national affiliation to influence judicial behaviour is simple in-group favouritism. Social psychologists have found considerable evidence that people tend to favour members of their own group, even where the relevant group categories are not otherwise socially salient and even when those categories are only temporarily ascribed to subjects for the purposes of experimental research (Tajfel 1974; Tajfel et al 1971). Not surprisingly, group biases of this kind seem to be especially acute where the relevant group categories are politicised and/or out-group members are perceived to be a threat of 
some kind (see Cairns et al 2006; and Tajfel \& Turner 1979) Apparently, judicial behaviour is not immune to this phenomenon. A line of research from the United States has found evidence of ethnic biases in the criminal justice system there (see for example Abrams et al 2012; and Glaeser \& Sacerdote 2003) and recent studies from Israel find evidence of ethnic bias in both bail hearings (Gazal-Ayal \& Sulitzeanu-Kenan 2010) and small claims awards (Shayo \& Zussman 2010). It seems plausible then that judicial decision-making in a deeply divided society such as Bosnia-Hercegovina would be prone to similar group biases.

In light of the above considerations, we propose to test the following hypothesis against the judges' voting records in non-unanimous abstract review cases:

\section{CO-ETHNIC PETITIONER HYPOTHESIS:}

The domestic judges will be more likely (all else equal) to find a constitutional violation where the challenge is brought by a co-ethnic petitioner.

It should be noted that evidence in support of this hypothesis would be consistent with either ethno-national attitudinal bias and/or in-group favouritism. Unfortunately, as we explain later, our data and research design do not allow us to distinguish between the observable implications of these two putative causes. However, given the political and social salience of ethno-national identity in Bosnia-Herzegovina, we would expect some combination of both.

\section{The Effects of Tenure}

Some commentators have speculated that the Court appears to be less ethno-nationally divided since the introduction of long-term tenure in 2003, possibly signaling "an era in which loyalty to entities or peoples is subordinated to legal professionalism and loyalty to the 
Constitution and the Court" (Feldman 2005: 660; see also Choudhry \& Stacey 2011). Indeed, although dissent rates have varied widely across both mandates, the overall rate of nonunanimous decisions during the long-term mandates is considerably lower; $17.2 \%$ of plenary decisions during the Court's long-term mandate (up to the end of 2013) were accompanied by at least one dissent, whereas $25.3 \%$ of decisions during the first 5 -year mandate were nonunanimous. That being said, the Court's caseload increased substantially after it assumed jurisdiction over human rights challenges from the now defunct Human Rights Chamber in 2003. ${ }^{29}$ Thus, the higher rate of unanimous decisions in the latter period may simply reflect a greater degree of "dissent aversion" - these judges are busier and so they may be less inclined to bother with writing dissenting opinions (see Epstein et al 2013: ch. 6).

Still, there are some general reasons to expect that long-term tenure might make a difference for patterns of judicial behaviour. As was noted earlier, the conventional wisdom is that life or long-term tenure are critical safeguards against undue political influence and interference. The Federalist Papers, for example, describe life tenure as the most important guarantee of the "independent spirit in the judges which must be essential to the faithful performance of so arduous a duty" (Hamilton 2009: 395). In a similar vein, contemporary ${ }^{29}$ The Human Rights Chamber was established under the terms of the Dayton Agreement as a parallel but temporary court for hearing human rights complaints in the aftermath of the war. The Chamber consisted of six national judges (appointed in the same way as judges of the constitutional court and adhering to the convention of parity as between constituent peoples) and eight international judges appointed by the Council of Europe. The Chamber's mandate expired in 2003, at which point a considerable backlog of pending cases was transferred to a temporary Human Rights Commission operating within the Constitutional Court. As we explain later, we do not consider these cases here because the ethnicity of the claimants cannot reliably be coded. 
governments and international organizations also cite long-term and life tenure as best practice. The International Bar Association's "New Delhi Standards" for judicial independence (1982: para. 22) state that "[j]udicial appointments should generally be for life, subject to removal for cause and compulsory retirement at an age fixed by law at the date of appointment" and that "[the institution of temporary judges should be avoided as far as possible long except where there exists a historic democratic tradition". Likewise, the US Agency for International Development's “Guidance for Promoting Judicial Independence and Impartiality" endorses life and long-term tenure as preferable to short-term appointments (2002). Many academic treatments of judicial independence concur with this conventional wisdom. La Porta et al, for example, treat long-term tenure as the core of judicial independence, reasoning that judges with life-tenure "are both less susceptible to direct political pressure and less likely to have been selected by the government currently in office" (2004: 453). In contrast, short-term renewable tenure is typically thought to be the worst arrangement for judicial independence because it creates obvious re-appointment pressures that may influence judicial decision-making (Salzberger \& Voigt 2002: 38; Sadurski 2014: 27). Between these two poles are non-renewable terms. Judges with non-renewable terms do not face reappointment pressures, but they may nevertheless (depending on the length of their mandate) feel pressured to placate powerful elites for the sake of later career opportunities (Sadusrki 2014: 28). ${ }^{30}$

${ }^{30}$ Some might be tempted to view non-renewable tenure as functionally equivalent to lifetenure - after all, judges under either arrangement have no need to worry about reappointment. We disagree. As Wojciech Sadurski explains, "judges who come to the end of their term... and yet are well before retirement age can be quite conscious of the fact that their future may be shaped by politicians, and this may contribute to their political dependence" (2014: 28). 
The empirical evidence on the effects of judicial tenure is by no means conclusive. Studies of state courts in the United States, where there is considerable variance in judicial tenure, suggest that judges who face reappointment pressures - in the form of political reappointment, contested elections, or uncontested retention elections - do behave differently. Brace and Hall (1997) find that otherwise liberal judges who face re-election or reappointment, and especially those with relatively short mandates, are significantly more likely to impose the death penalty (se also Canes-Wrone et al 2014). In a similar vein, Shepherd (2009) finds that judges on state supreme courts who face re-election or reappointment are more likely to decide cases in ways that favour the political preferences of their re-appointers. The cross-national comparative evidence, however, is less definitive (see Hayo \& Voigt 2007; Smithey \& Ishiyama 2002; Herron \& Randazzo 2003; Helmke \& Rosenbluth 2009). In a recent cross-national study, Melton and Ginsburg (2014) find that long-term tenure does enhance independent decision-making, but only in tandem with apolitical selection systems and only in authoritarian or transitional democracies. There is also at least some evidence to suggest that relatively short-term appointments do not necessarily inhibit judicial independence (see Chandrachud 2013). The Constitutional Court of Colombia, for example, is noted for taking assertive stands against government, despite the fact that the judges serve non-renewable terms of only eight years (Landau 2010; Schor 2009). In sum, our understanding of when and how judicial tenure matters across different courts and in different contexts is still in the relatively early stages of development.

With respect to the Constitutional Court of Bosnia-Herzegovina, whether or not we should expect differences in tenure to actually moderate the influence of ethno-national affiliation on judicial behaviour surely depends, at least in part, on how we model the underlying cause of that influence. According to both the attitudinal and in-group favouritism models outlined above, tenure should make no significant difference because the influence of 
ethno-national affiliation is sincere and stems from a lack of impartiality (as opposed to independence). But a strategic model of judicial behaviour might attribute a tendency to side with co-ethnic petitioners to the influence of sanctions and rewards deployed by political elites (Epstein \& Jacobi 2010): if judges with shorter mandates lack independence relative to long-term appointed judges, they will be relatively more prone to curry the favour of political elites in the hope of gaining post-appointment advantages; and if the relationship between judges and political elites follows the usual pattern of communal "pillarization" associated with deeply divided polities, we should expect this dynamic to play out primarily within each communal pillar (Luther: 1999). ${ }^{31}$ In other words, political elites will reward co-ethnic judges for friendly decisions and, consequently, shorter term judges will be relatively more inclined to favour the preferences of co-ethnic elites. In this model, tenure should make a significant difference because the influence of ethno-national affiliation is (at least in part) strategic and reflects a lack of independence (as opposed to impartiality). The plausibility of this conjecture in the context of Bosnia-Herzegovina is strengthened by the fact that at least two judges from the Constitutional Court's first mandate did actually go on to hold government or public sector jobs of some kind after their terms expired. Accordingly, we propose to test the following hypothesis:

\section{THE SHORT-TERM TENURE HYPOTHESIS}

Any propensity to favour co-ethnic petitioners will be more pronounced in the behaviour of judges with five-year terms than in those judges who enjoy long-term tenure.

\footnotetext{
31 "Pillarization" here refers to creation and maintenance of parallel networks and organizational structures that tightly correspond to the salient communal divisions.
} 
But there is another, less categorical, way to think about the effects of tenure. The simple attitudinal model we sketched above presumes that the judges' political preferences are effectively static and constantly revealed across time (Spaeth 1979: 119-20). In other words, an ethno-nationalist judge will remain an ethno-nationalist and consistently tend to decide cases in accordance with her ethno-nationalist preferences. These assumptions may not be valid. Several studies of judicial behaviour in the United States have noted the phenomenon of "ideological drift" - some initially conservative or liberal judges appear to become more or less so over time (see e.g. Epstein et al 2007). Other studies suggest general "acclimation effects", finding that the ideological aspect of judicial decision-making is relatively less predictable early in a judge's tenure but tends to settle into more a predictable disposition after the judge "acclimates" to her role on the court (Boyea 2010; Collins 2008; Kaheny et al 2008; Hagle 1993; Hettinger et al 2003; Hurwitz and Stefko: 2004; Wood et al 1998). Hurwitz and Stefko (2004), for example, find that attitudinal influences "progressively dominate" decision-making at the US Supreme Court - the justices become increasingly likely over the course of their tenure to depart from precedent in ways that track political ideology, an effect that the authors attribute to the justices gradually adjusting to the power they wield on a relatively unconstrained apex court (128). As we explained above, the Bosnian Constitutional Court is also a relatively unconstrained apex court. It is plausible then that the Court's judges experience a similar kind of acclimation whereby ethnonationalism comes to play a greater role in their decision-making over time. Furthermore, the longer a judge serves on a court, the more opportunity she has to learn about the preferences and tendencies of other judges (Collins 2008). Thus, a judge who initially makes a determined effort to decide cases legalistically (and without regard to ethno-national affiliation) may become increasingly jaded as she observes other judges deciding cases along clear ethno-national lines. Consequently, she may become less hesitant to give rein to her 
own biases as her tenure goes on. In light of these conjectures, we propose to test the following hypothesis:

THE ACCLIMATION HYPOTHESIS:

The propensity to favour co-ethnic petitioners will increase as a judge accumulates years of tenure on the Court.

\section{Data and Preliminary Analysis}

Our analysis relies on an original dataset of all non-unanimous abstract review decisions of the Constitutional Court terminated on the merits from the beginning of the Court's work in 1997 to the end of 2013. The unit of analysis is the individual judge's 'vote' $(\mathrm{N}=190)$. Our focus on non-unanimous decisions is based on a well-rehearsed rationale: a dissent is the clearest indication that the law at issue in the dispute was sufficiently indeterminate as to present the judges with a genuine choice about which way to decide (Pritchett 1948; Tate and Sittiwong 1989)..$^{32}$ Our decision to focus on abstract review cases is motivated by two considerations. First, the Co-Ethnic Petitioner Hypothesis requires that we can reliably code for the ethnicity of the claimant in the cases we look at. Although one might be able to make an educated guess at the ethnicity of a claimant on the basis of his or her surname, most of the

\footnotetext{
${ }^{32}$ This is not to say that the outcome in unanimous decisions is a foregone conclusion. But, given the methods we use here, including unanimous decisions would limit the variance that can be leveraged to explain individual judicial choice (Tate and Sittiwong 1989: 902; for an example of how data on unanimous decisions can be used to study judicial behaviour, see Epstein et al 2013).
} 
Court's published decisions in appeals and referrals from lower courts use only the parties' initials. And even where they are given in full, names are not necessarily reliable markers for ethno-national affiliation; many surnames are ethnically ambiguous and mixed ethnic heritage further complicates coding (even for claimants with names that are recognizably Muslim). The advantage then of abstract review cases is that the petitioners are always politicians whose ethno-national affiliation is either widely known or discernible from publicly available data. The price we pay for focusing on abstract review decisions is that we cannot determine if or how far the effect of ethno-national affiliation extends to the rest of the Court's work (where the issues at stake may well be less ethno-nationally charged and of relatively little constitutional consequence).

With respect to the characteristics of the decisions, our data include the level of government under review, the type of legal issue or issues raised in each case ${ }^{33}$ as well as the ethno-national affiliation and political party of the petitioner(s). With respect to the judges, the data include the ethno-national affiliation of each judge, the number of years already served in their tenure, the number of years remaining in the judges' mandates at the time of the decision, and the political party (or parties) controlling the relevant entity legislature at the time of the judges' appointment. ${ }^{34}$ We use dichotomous variables to code the individual

${ }^{33}$ If a case relates to more than one distinct piece of legislation or government action, we include each as a separate set of observations, provided that the judges are non-unanimous with respect to each set. In other words, only the non-unanimous components of such cases are included in the dataset.

${ }^{34}$ Based on what we know about how appointment in the entity legislatures works, we code Bosniak judges has having been appointed by the dominant Bosniak party in the $\mathrm{FBiH}$ legislature at the time of appointment (which in all cases is the SDA) and Croat judges as having been appointed by the HDZ, which has always been the dominant Croat party in the 
decision of each judge (coded " 1 " if they are in the majority finding a constitutional violation or, where the majority does not find a violation, if they author a dissent to that effect). Summary statistics for all observations are displayed in Table 1.

Table 1. Summary Statistics for Abstract Review Decisions

\begin{tabular}{lc}
\hline Variable & $\begin{array}{c}\text { Mean } \\
\mathrm{N}=190)\end{array}$ \\
\hline Judge votes to find a violation & .342 \\
\hline Court finds a violation & .411 \\
\hline $\begin{array}{l}\text { Ethno-national affiliation of } \\
\text { petitioner } \\
\text { - Bosniak petitioner }\end{array}$ & .584 \\
- Serb petitioner & .279 \\
- Croat petitioner & .137 \\
\hline Case challenges FBiH & .184 \\
\hline Case challenges RS & .489 \\
\hline Case challenges BiH & .326 \\
\hline Bosniak Judge & .226 \\
\hline Serb Judge & .2 \\
\hline Croat Judge & .232 \\
\hline International Judge & .342 \\
\hline Case raises an ECHR issue & .311 \\
\hline 5-Year Mandate & .5 \\
\hline
\end{tabular}

A preliminary analysis of this data does indeed reveal patterns which suggest that ethno-national affiliation influences the Court's decision-making in abstract review cases.

FBiH. We code Serb judges as having been appointed by whichever Serb party controlled the RS legislature at the time of appointment. 
Table 2 reports the fraction of judges' votes finding a constitutional violation by unit of government under review. For ease of comparison, these percentages are graphed in Figure 1.

Table 2. Fraction of Votes for a Constitutional Violation in Abstract Review Decisions

\begin{tabular}{lccc}
\hline & $\mathrm{BiH}$ & $\mathrm{RS}$ & $\mathrm{FBiH}$ \\
\hline Bosniak judge & $2 / 14(.143)$ & $15 / 21(.714)$ & $3 / 8(.375)$ \\
Serb judge & $11 / 13(.846)$ & $1 / 17(.059)$ & $1 / 8(.125)$ \\
Croat judge & $5 / 14(.357)$ & $7 / 22(.318)$ & $1 / 8(.125)$ \\
International judge & $1 / 21(.048)$ & $12 / 33(.364)$ & $6 / 11(.545)$ \\
Total & $19 / 62(.306)$ & $35 / 93(.376)$ & $11 / 35(.314)$ \\
& & & \\
\hline
\end{tabular}

Figure 1. Percentage of Votes for a Constitutional Violation in Abstract Review Decisions

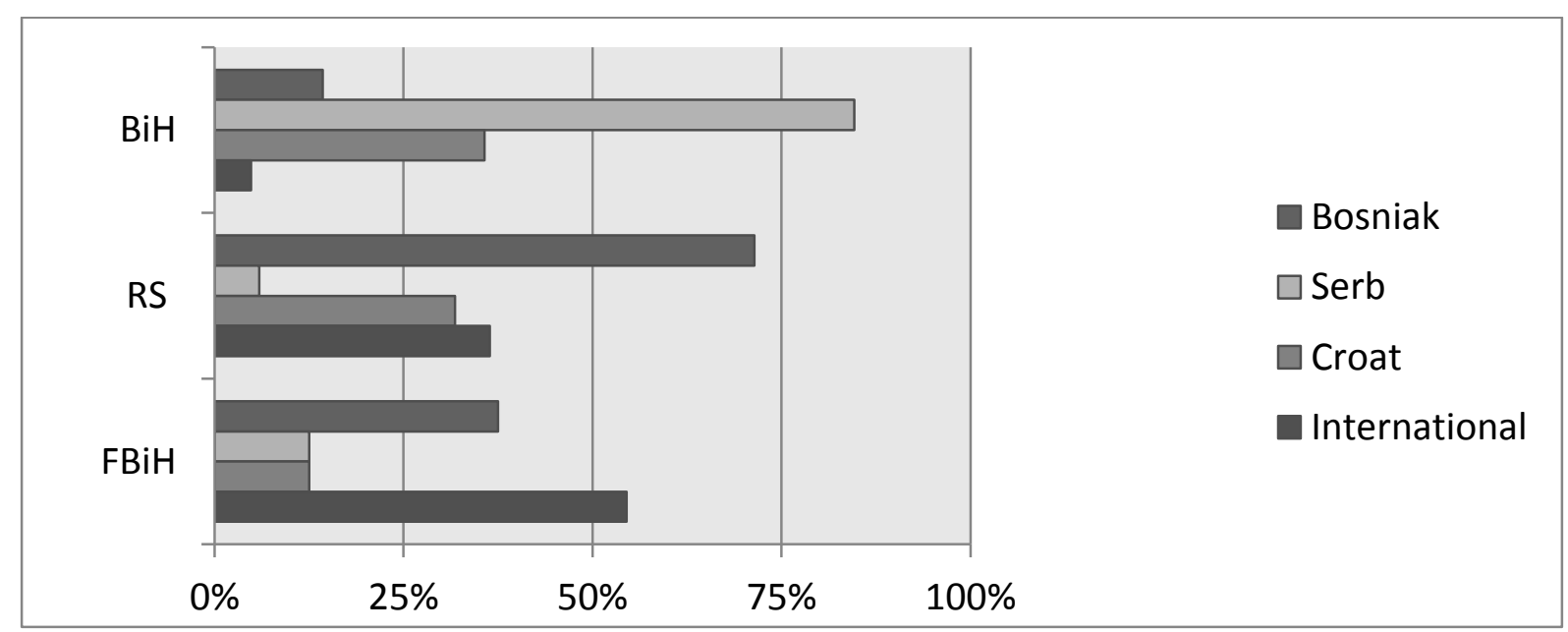

As can be seen, international judges and Bosniak judges almost never vote against a law or government action from $\mathrm{BiH}$ while Serb judges do so in nearly $87 \%$ of observations. In 
contrast, in cases involving RS, Serb judges virtually never vote to find a violation (1/17) while Bosniak judges do so in about $71 \%$ of observations. With respect to cases involving $\mathrm{FBiH}$, international judges find a violation in over $50 \%$ of observations, while Serb and Croat judges find violations in only about $12 \%$ of observations. These patterns are, broadly speaking, consistent with the constitutional preferences espoused by the main ethnonationalist parties, as well as the findings of public opinion research on the constitutional preferences of each ethno-national group; Bosniaks tend to be centralists, while Croats and Serbs tend to be decentralists (Prism Research 2013: 44). In other words, the observed patterns of judicial behaviour appear to reflect ethno-national perspectives. More to the point for our purposes here, the data is consistent with the Co-Ethnic Petitioner Hypothesis. As can be seen from Table 3 and Figure 2, in observations from abstract review cases in which the judge and petitioner(s) are not co-ethnics, only about $23 \%$ of votes (34 out 147) find a constitutional violation. In contrast, where the judge and (at least one) petitioner are coethnics, $72 \%$ of votes (31/43) find a constitutional violation. Furthermore, and consistent with the Short-Term Tenure Hypothesis, the tendency to find a constitutional violation where the judge and (at least one) petitioner are co-ethnics is slightly higher (roughly $77 \%$, or 17/22) for observations from the 5-year mandate than it is for observations from the longterm mandate (about $67 \%$, or $14 / 21$ ).

Table 3. Fraction of Votes for a Constitutional Violation in Abstract Review Decisions

\begin{tabular}{lccc}
\hline & All Observations & Short-Term Mandate & Long-Term Mandate \\
\hline $\begin{array}{l}\text { Non Co-Ethnic } \\
\text { Petitioner }\end{array}$ & $34 / 147(.23)$ & $18 / 73(.25)$ & $16 / 74(.22)$ \\
Co-ethnic Petitioner & $31 / 43(.72)$ & $17 / 22(.77)$ & $14 / 21(.67)$ \\
\hline
\end{tabular}

Figure 2. Percentage of Votes for a Constitutional Violation in Abstract Review Decisions 


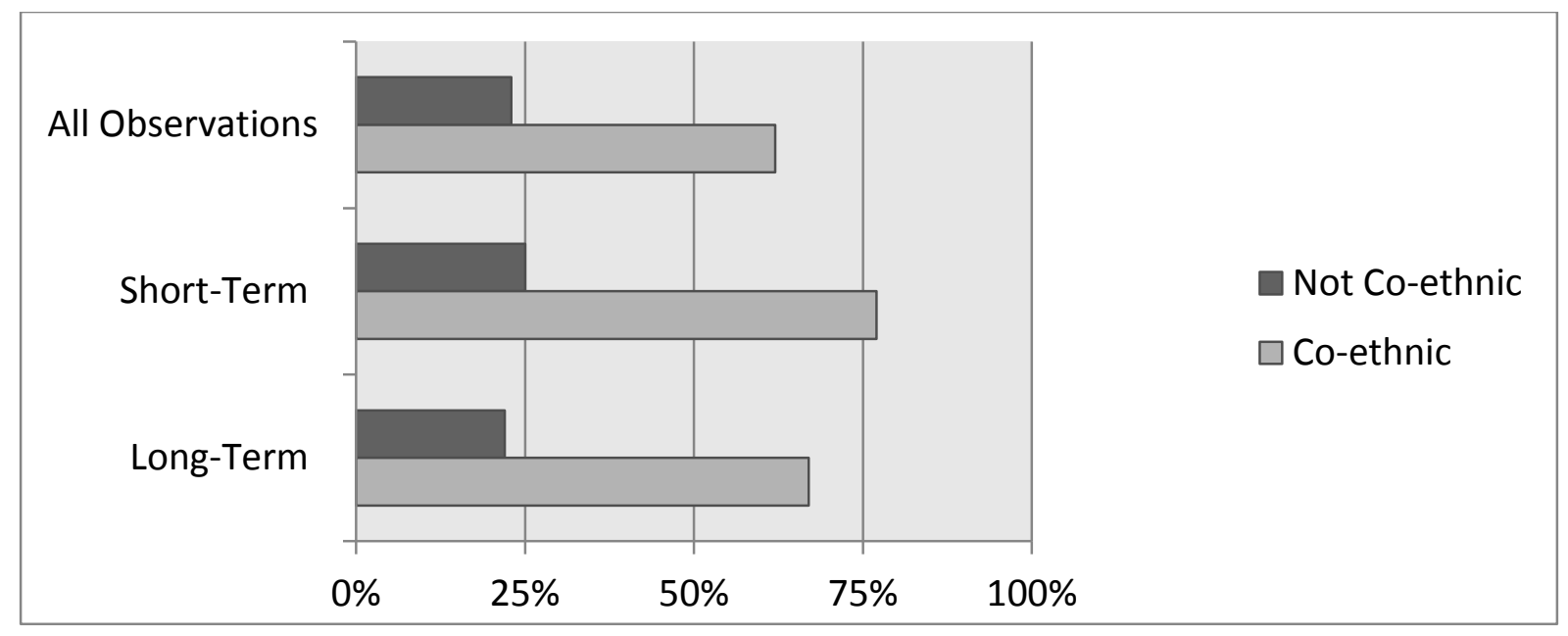

The above-noted patterns in the decision-making of the individual justices have important consequences for the aggregate outcomes of the Court's decisions. Taking into account both unanimous and non-unanimous decisions, abstract review challenges to the RS and $\mathrm{FBiH}$ entities have a successes rate of $47.6 \%$ and $50 \%$ respectively. In contrast, challenges to the $\mathrm{BiH}$ level only succeed in $26.3 \%$ of cases. Bosniak petitioners are also the most successful challengers, bringing 29 of 67 (or 43.5\%) of the abstract review challenges and winning in 15 (or 51.7\%) of these. In contrast, Serb petitioners brought 31 of these challenges, of which they won only 6 (or 19.4\%), while Croats brought only 7 challenges, winning in only 3 (or $42.9 \%$ ) of them. In short, the Court's output would seem to favour Bosniak constitutional preferences, upholding central state laws in the vast majority of cases but regularly disciplining the entities.

As suggestive as this preliminary analysis might be, it only provides cursory evidence of the effects of ethno-nationalism and judicial tenure on judicial behaviour. In what follows, we test our hypotheses against the data in a more rigorous and nuanced way.

\section{Testing the Co-Ethnic Petitioner Hypothesis}


To test the Co-Ethnic Petitioner Hypothesis, we estimate logit regression models with standard errors clustered by judge. ${ }^{35}$ The dependent variable is the judge's 'vote', coded "1" to find a constitutional violation and " 0 " if otherwise. The main independent variable of interest is a dummy variable, coded " 1 " if at least one of the abstract review petitioners and the judge are co-ethnics. ${ }^{36}$

Our models include several controls for potential confounding variables. Arguably the most important of these is a variable to control for alignment between the judges' appointing political party and the petitioners' political party. The Co-Ethnic Petitioner Hypothesis is motivated by the theory that the judges will favour co-ethnic elites because they share the same ethno-nationalist policy preferences and/or because of in-group favouritism. But ethnonationalist politics and ethnicity are likely to be highly correlated with party political affiliation in a divided society. Thus, a tendency to favour co-ethnic challengers may be partly (or even entirely) a function of political partisanship. Indeed, party-political loyalty has been found to be a strong predictor of judicial behaviour on other apex courts (see for example Garoupa et al 2013; and Hönnige 2009). Thus, we include a dummy variable to control for the possibility that the domestic judges may be more likely, other things being equal, to support challenges brought by the political party that appointed them. Including this

\footnotetext{
${ }^{35}$ In so far as the same judges feature in the dataset across numerous observations, "naïve" standard errors may under-or over-estimate the significance of certain judge-specific effects (for sophisticated discussion of the pros and cons of using clustered standard errors, see Zorn 2006).

${ }^{36}$ Some abstract review cases are brought by a group of petitioners representing more than one ethno-national community. For example, a petition may be brought by a group of Serbs and Croat politicians, in which case the co-ethnic petitioner variable will take the value of "1" for both the Serb and Croat judges deciding that case.
} 
variable comes at some cost - we are forced to drop nine observations (i.e. one case) in which the party of the petitioners could not be confidently determined. It should also be noted that in all challenges by brought by Croats, the petitioners belonged to the same party as the party that appointed the Croat judges (i.e. HDZ). Accordingly, we cannot confidently distinguish between the effects of party-political loyalty and ethno-national affiliation with respect to Croat judges. Naturally, we also include categorical variables to control for the ethno-national affiliation of the judge (using the international judges as the reference category) and the petitioner (using Croat judges as the reference category). The rationale here is that, all else equal, some groups may be more prone to bringing relatively more spurious constitutional challenge and some groups of judges may be relatively more restrained (or "activist") than others. Indeed, these control variables are essential; the main independent variable of interest - ethnic alignment between the judge and petitioner - is effectively a product of them.

In addition to the above, we include several ancillary control variables. We use a categorical variable to control for the unit of government whose law or action is being challenged (using the $\mathrm{BiH}$ state level as the reference category); it is possible that some units of government, particularly RS, may be more constitutionally "rebellious" than others. In addition, we use a dummy variable to control for the influence of the European Convention on Human Rights (ECHR). The Constitution of Bosnia-Herzegovina incorporates the ECHR, making it directly enforceable and superior to all ordinary domestic law ${ }^{37}$ it is conceivable that, all else equal, judges may be more likely to find a constitutional violation in cases where they can appeal to the external authority of the ECHR and the jurisprudence of the European Court of Human Rights. Finally, we use a dummy variable to control for whether or not the case was decided during the initial 5-year short-term mandate. The rationale here is that the political context during those first five years may have been more or less prone to meritorious

${ }^{37}$ Art.II.II. 
challenges or relatively more or less "activist" judgments (although we have no theoretical expectation either way).

The first of our models tests the general effect of a co-ethnic petitioner on the probability of a judge finding a constitutional violation. Models 2 uses interaction terms to test if the effect is significant for both Bosniak and Serb judges taken separately (for the reasons noted above, we do not do the same for Croat judges). Model 3 replaces the partypolitical alignment variable with a control variable that roughly tracks ideological proximity between the petitioner's party and the judge's appointing party (coded " 1 " if both are generally right of centre or both are generally left of centre). Admittedly, this is a rather blunt proxy for ideological affinity. But if we assume that the political parties appoint judges who are ideologically proximate to them, Model 3 should give us some sense of the relative strength of more traditional (i.e. non-nationalist) left-right attitudinal influences (we restrict observations to just the domestic judges in Model 3 because we do not presently have any way to code the probable ideological leanings of the international judges).

Table 4. Logit Regressions for Finding a Constitutional Violation in Non-Unanimous Decisions Robust standard errors (clustered by judge) in parentheses; $* \mathrm{p}<0.05 ; * * \mathrm{p}<0.01$

\begin{tabular}{lccc}
\hline & Model 1 & Model 2 & Model 3 \\
\hline Petitioner is co-ethnic of judge & $3.786^{* *}$ & - & $4.1^{*}$ \\
& $(.856)$ & & 1.771 \\
\hline Petitioner is from judge's appointing & -1.074 & .41 & - \\
political party & $(.733)$ & $(.684)$ & .0737 \\
\hline Petitioner and judge's appointing & - & - & $(.585)$ \\
party are ideologically proximate & & -.948 & -1.99 \\
\hline Bosniak judge & -1.187 & $(.674)$ & $(1.74)$ \\
\hline Bosniak petitioner & $(.791)$ & .191 & .0232 \\
& .716 & $(1.619)$ & $(2.12)$ \\
\hline Bosniak judge*Bosniak petitioner & $(1.447)$ & $2.211^{*}$ & - \\
& - & $(.942)$ & - \\
\hline Serb judge & & $-1.017 * *$ & $(.381)$ \\
& -.737 & $-3.3 * *$ & -3.363 \\
\hline Serb petitioner & $(.384)$ & $(1.178)$ & $(2.02)$ \\
\hline
\end{tabular}




\begin{tabular}{lccc}
\hline Serb judge*Serb petitioner & & $4.691 * *$ & - \\
\hline Croat judge & -.387 & $(1.786)$ & - \\
& $(.521)$ & & -2.52 \\
\hline Challenge to FBiH Law or Gov't & -.776 & -.696 & $(1.64)$ \\
Action & 1.356 & $(1.62)$ & -2.4 \\
Challenge to RS Law or Gov't & -1.305 & -1.218 & $(1.828)$ \\
Action & 1.396 & $(1.68)$ & .022 \\
The case raises an ECHR Issue & -.146 & -.262 & $(.763)$ \\
& .507 & $. .506)$ & -.213 \\
\hline Case is from short-term mandate & .182 & .107 & $(.44)$ \\
& $(.372)$ & $(.374)$ & 1.287 \\
\hline Constant & .544 & .285 & 1.915 \\
& 1.432 & $(.739)$ & -54.571 \\
\hline Log pseudolikelihood $=$ & -92.480 & -93.038 & 0.336 \\
Pseudo R2 $=$ & 0.209 & 0.205 & 74.89 \\
Wald chi2(9) $=$ & 91.80 & 137.31 & 0.0000 \\
Prob chi2 $=$ & 0.0000 & 0.0000 & 125 \\
Number of obs $=$ & 181 & 181 & \\
\hline
\end{tabular}

As can be seen in Table 4, the results provide robust support for the Co-Ethnic Petitioner Hypothesis. Model 1 shows that an alignment of ethnicity between the petitioner and the judge significantly increases the likelihood of finding a violation, even when controlling for the influence of party-political appointment. The difference in predicted probabilities for finding a constitutional violation in these cases is also a substantively meaningful one. All else being equal, the probability of a judge finding a constitutional violation in abstract review cases is only $.20[.15, .26]$, but it rises to $.84[.74, .94]$ when the judge and petitioner are co-ethnics. Robustness tests on subsets of the data show that this effect is significant (and comparable) for all three groups of domestic judges: the average marginal effect (or "AME") of a co-ethnic petitioner on the probability of finding a constitutional violation is .63 $[.49, .78]$ for Bosniak judges; .64 [.49, .78] for Serb judges, and .67 [.52, .82] for Croat judges. $^{38}$ Model 2 provides additional confirmation that the effect in question is significant for both Bosniak and Serb judges (the interaction terms with the ethnicity of the challenger are both positive and statistically significant) and Model 3 shows that the effect of a coethnic petitioner remains significant when controlling for left-right ideological proximity ${ }^{38}$ We use Stata's "subpop" command to calculate these AMEs. 
between the petitioner and the judge (indeed, putative left-right ideological proximity seems to make virtually no difference). Across all three models, the effect of a co-ethnic petitioner is robust to alternate specifications that drop the ancillary control variables (i.e. unit of government being challenged, the mandate, and the presence of an ECHR issue).

\section{Testing the Tenure Hypotheses}

To test the tenure hypotheses, we ran variations of Model 1, but with interaction terms relating to the judge's tenure on the court. ${ }^{39}$ In Model 4, we test for a simple interaction between short-term tenure and the effects of a co-ethnic petitioner; if the Short-Term Tenure Hypothesis is correct, the effect of a co-ethnic petitioner should be enhanced by short-term mandates. ${ }^{40}$ This approach does not account for the fact that the long-term tenured judges were appointed at various ages and so the length of their mandates, i.e. the number of years between their appointment and mandatory retirement at age 70, also varies. It is plausible that there may be little practical difference between the behaviour of a judge appointed for a 5-year term at the age of 55 and a judge appointed at the age of 65 with mandatory at age 70. Accordingly, in Model 5, we use an interaction term for (the natural log of) the length of the judge's tenure, i.e. the number of years from the time of her appointment to the expiry of her

${ }^{39}$ Our methodology for interaction effects in the following analysis closely follows the advice of Brambor et al (2006).

${ }^{40}$ Because two of the short-term domestic judges in our dataset, Judge Marko Arsović, (a Serb) and Judge Mirko Zovko (a Croat), were already over the age of 60 at the time of appointment they might, arguably, be less affected by post-appointment pressures and incentives. Accordingly, we ran an alternate specification of Model 4 in which we exclude observations of these judges. 
mandate. The idea here is to determine if, regardless of the formal tenure category, the effect of ethno-national affiliation on judicial behaviour is amplified by relatively shorter terms. Finally, Model 6 tests the Acclimation Hypothesis by including an interaction term for the (natural $\log$ ) of the number of years of tenure accumulated at the time of the judge's decision. If the Acclimation Hypothesis is correct, the effect of ethno-national affiliation should be amplified as years of accumulated tenure increase. The results for these models are reported in Table 5.

Table 5. Logit Regressions for Interaction Effects of Ethno-national Affiliation with Tenure Robust standard errors clustered by judge in parentheses; $* \mathrm{p}<0.05 ; * * \mathrm{p}<0.01$

\begin{tabular}{|c|c|c|c|}
\hline & Model 4 & Model 5 & Model 6 \\
\hline Petitioner is co-ethnic of judge & $\begin{array}{l}2.635^{*} \\
(.791)\end{array}$ & $\begin{array}{c}2.44 \\
(1.363)\end{array}$ & $\begin{array}{l}1.465 \\
(1.22)\end{array}$ \\
\hline Judge has short-term mandate & $\begin{array}{l}.278 \\
(.416)\end{array}$ & - & - \\
\hline Length of judge's mandate & & $\begin{array}{l}-.147 \\
(.28)\end{array}$ & - \\
\hline Accumulated tenure at time of decision & - & - & $\begin{array}{l}-.457 \\
(.420)\end{array}$ \\
\hline $\begin{array}{l}\text { Co-ethnic petitioner*short-term } \\
\text { mandate }\end{array}$ & $\begin{array}{l}.211 \\
(.738)\end{array}$ & - & - \\
\hline $\begin{array}{l}\text { Co-ethnic petitioner*length of judge's } \\
\text { mandate }\end{array}$ & - & $\begin{array}{l}.079 \\
(.508)\end{array}$ & - \\
\hline $\begin{array}{l}\text { Co-ethnic petitioner*accumulated } \\
\text { tenure }\end{array}$ & - & & $\begin{array}{l}.829 \\
(.715)\end{array}$ \\
\hline $\begin{array}{l}\text { Petitioner is from judge's appointing } \\
\text { political party }\end{array}$ & $\begin{array}{l}-.228 \\
(.775)\end{array}$ & $\begin{array}{l}-.076 \\
.784\end{array}$ & $\begin{array}{l}-.126 \\
(.828)\end{array}$ \\
\hline Bosniak judge & $\begin{array}{l}-.907 \\
(.655)\end{array}$ & $\begin{array}{l}-.909 \\
(.637)\end{array}$ & $\begin{array}{l}-.956 \\
(.607)\end{array}$ \\
\hline Serb judge & $\begin{array}{l}-.851^{*} \\
(.416)\end{array}$ & $\begin{array}{l}-.873^{*} \\
(.443)\end{array}$ & $\begin{array}{l}-.999 \\
(.523)\end{array}$ \\
\hline Croat judge & $\begin{array}{l}-.376 \\
(.450)\end{array}$ & $\begin{array}{l}-.364 \\
(.437)\end{array}$ & $\begin{array}{l}-.375 \\
(.447)\end{array}$ \\
\hline $\begin{array}{l}\text { Challenge to FBiH Law or Gov’t } \\
\text { Action }\end{array}$ & $\begin{array}{l}-.027 \\
(.719)\end{array}$ & $\begin{array}{l}-.025 \\
(.716)\end{array}$ & $\begin{array}{l}-.085 \\
(.708)\end{array}$ \\
\hline Challenge to RS Law or Gov’t Action & $\begin{array}{c}.190 \\
(.474)\end{array}$ & $\begin{array}{l}.173 \\
.(48)\end{array}$ & $\begin{array}{l}.138 \\
(.49)\end{array}$ \\
\hline The case raises an ECHR Issue & $\begin{array}{l}-.458 \\
(.415)\end{array}$ & $\begin{array}{l}-.483 \\
(.415)\end{array}$ & $\begin{array}{l}-.493 \\
(.423)\end{array}$ \\
\hline Constant & $\begin{array}{l}-.918 \\
(.464)\end{array}$ & $\begin{array}{l}-.443 \\
(.743)\end{array}$ & $\begin{array}{c}.008 \\
(.813)\end{array}$ \\
\hline
\end{tabular}




\begin{tabular}{lccc}
\hline Log pseudolikelihood $=$ & -99.159 & -99.472 & -98.842 \\
Pseudo R2 $=$ & 0.152 & 0.15 & 0.155 \\
Wald chi2 $(9)=$ & 85.95 & 68.12 & 53.67 \\
Prob $>$ chi2 $=$ & 0.000 & 0.000 & 0.0000 \\
Number of obs $=$ & 181 & 181 & 181 \\
\hline
\end{tabular}

As the results for Model 4 illustrate, contrary to the predictions of the Short-Term Tenure Hypothesis, short-term tenure per se does not seem to significantly amplify the tendency to side with a co-ethnic petitioner (see Table 5). The coefficient for the relevant interaction term is not significant. And although the predicted probability of a judge finding a constitutional violation in cases of a co-ethnic petitioner is somewhat higher for short-term tenured judges $(.83[.65,1.0])$ then it is for long-term appointed judges $(.75[.54, .96])$, the AME of a co-ethnic petitioner on the probability of finding a constitutional violation does not differ significantly as between long-term and short-term tenured judges. For the former, the AME of a co-ethnic petitioner is $.55[.31, .80]$, while for the latter it is .58 [.34, .82]. The estimated "contrast" between these two marginal effects is only $0.03[-.20, .27]$, a difference which is clearly not significant. ${ }^{41}$

The results of Model 5, where we substitute the formal tenure category for number of years in the judge's term, also fail to support the Short-Term Tenure Hypothesis. In this case, ${ }^{41}$ These results are robust to an alternate specification of Model 4 that excludes those shortterm appointed judges who were appointed over the age of 60 . In fact, with this specification the marginal effects of a co-ethnic petitioner for both long-term tenured and short-term tenured judges are virtually identical; the AME is .55 [.31, .79] for the former and $.55[.29$, .81] for the latter. 
that the coefficient of the interaction term here is insignificant is not, all on its own, hard evidence against the hypothesis. The coefficient of an interaction term $\mathrm{XZ}$ only reflects the effect of $\mathrm{X}$ on $\mathrm{Y}$ when both $\mathrm{X}$ and $\mathrm{Z}$ are greater than zero. Thus, where $\mathrm{Z}$ is a continuous variable, "it is perfectly possible for the marginal effect of $\mathrm{X}$ on $\mathrm{Y}$ to be significant for substantively relevant values of the modifying variable $\mathrm{Z}$ even if the coefficient on the interaction term is insignificant" (Brambor et al 2006: 74; see also Berry et al 2010). Accordingly, to determine if there is a significant interaction between $\mathrm{X}$ and $\mathrm{Z}$, one needs to look beyond the coefficients and calculate the marginal effects of $\mathrm{X}$ for meaningful values of $\mathrm{Z}$ (Brambor et al 2006). In light of these considerations, we estimate and plot the AME of a co-ethnic petitioner across the spectrum of observed values for term length. As Figure 3 shows, the effect of a co-ethnic petitioner on the probability of finding a constitutional violation is significant and virtually static across this entire range and so it seems then that the length of a judge's tenure does not enhance (or diminish) the effect.

\section{Figure 3.}

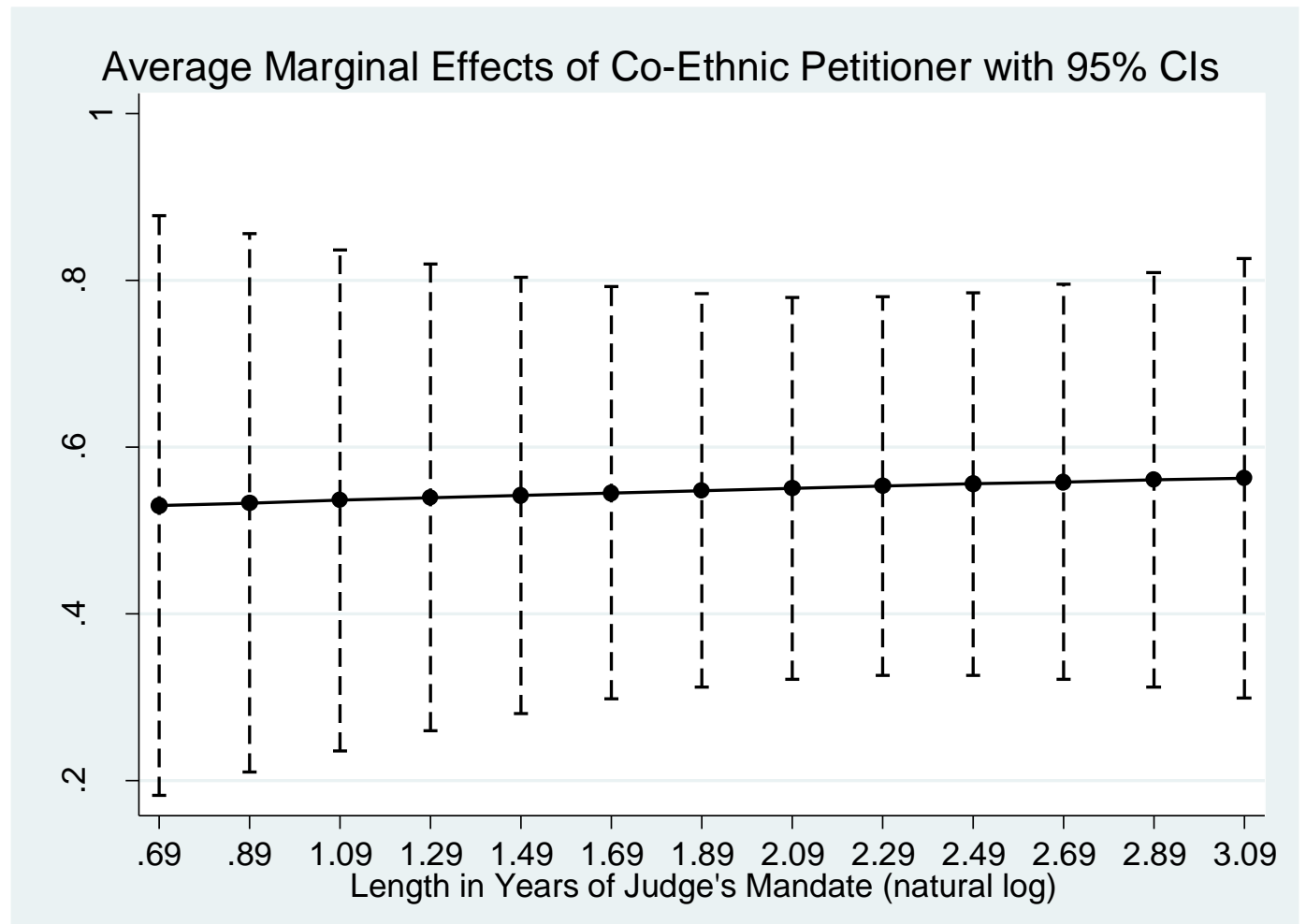


Turning now to Model 6, where we test the Acclimation Hypothesis, we do find some affirmative evidence. Again the interaction term is insignificant. However, because the conditioning variable here is continuous, we follow the same procedure as above and calculate and the AMEs of a co-ethnic petitioner across the range of observed values for accumulated tenure at the time of the judges' decisions. This time the plot does suggest a positive interaction (see Figure 4). The effect of a co-ethnic petitioner on the probability of finding a constitutional violation is significant at all but the lowest two values in this range and, as the Acclimation Hypothesis predicts, this effect increases with years of accumulated tenure. In other words, the effect of ethno-national affiliation on judicial behaviour appears to be enhanced by time served on the court.

\section{Figure 4.}

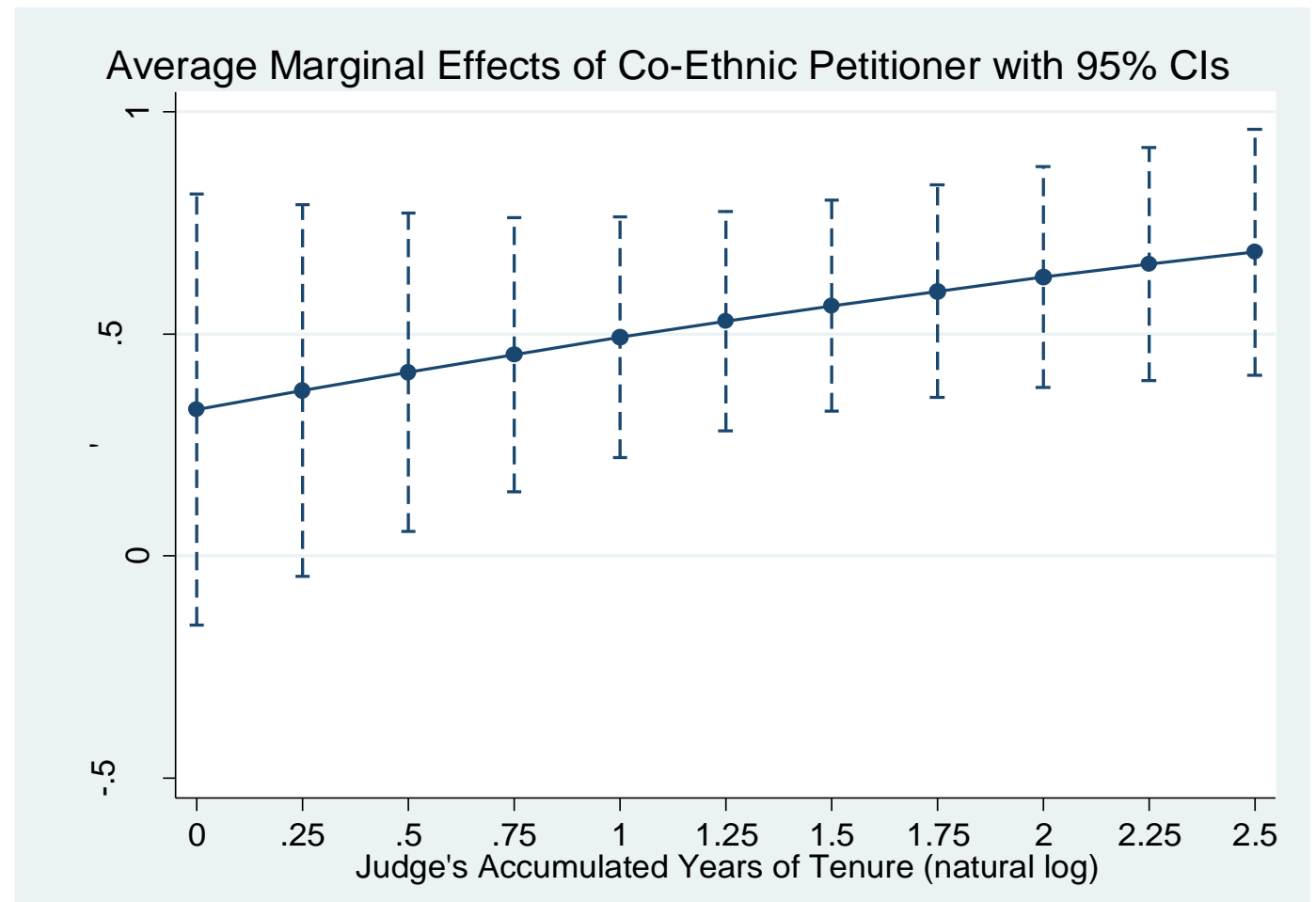

\section{Discussion and Conclusion}


Before discussing the importance of these findings, a few caveats are warranted. First of all, as we noted earlier, our data relates only to abstract review cases and so we cannot generalize here about the influence of ethno-national affiliation across the Court's entire caseload. Abstract review challenges make up about $20 \%$ of the cases decided in the period we consider and these cases are inherently political and ethno-nationally charged (they are initiated by politicians mobilized along ethno-national lines). Thus, a finding of ethnonational bias in abstract review cases does not necessarily tell us anything about the judges' behaviour in appeals or referrals from lower courts. It is certainly plausible that these other aspects of the Court's jurisdiction, in so far as they may be more concerned with individual claims of right than ethno-national politics, are relatively unaffected by the influence of ethno-national affiliation. Indeed, had we been able to reliably code the ethnicity of claimants in these other cases, we might have been able to determine whether the observed influence of ethno-national affiliation on judicial behaviour is driven by ethno-nationalist political preferences or simple inter-group biases - a finding that ethno-national affiliation is not a significant predictor of judicial behaviour in these other cases, where big constitutional controversies are not the norm, would suggest that the influence we observe in the abstract review cases is truly attitudinal and not merely a consequence of in-group favouritism. Future research (we hope) may yet find a way to surmount the coding challenge we faced. Second, despite their political nature, most of the Court's abstract review decisions decided during the period we consider are unanimous (roughly 66\%). This much suggests that, in the bulk of the Court's work, other factors (e.g. legal reasoning, dissent aversion) are more influential than ethno-national affiliation with respect to how the judges vote. Finally, our dataset - though inclusive of all non-unanimous abstract review decisions from 1997 to the end of 2013 - is ultimately only a sample from a particular slice of history. What is true of 
these judges' during this period of time may not be true of the same or future judges in the future.

These caveats aside, the evidence considered here strongly suggests that ethnonational affiliation exerts a significant influence on the Court in non-unanimous abstract review decisions. When the judges do disagree, ethno-national affiliation is a powerful predictor of how they divide and this influence cannot be reduced to simple party-political loyalty. Moreover, the influence of ethno-national affiliation appears to be unaffected by the length of the judges' mandates; long-term appointed judges do not categorically differ from their short-term counterparts in their propensity to decide cases along ethno-national lines. In fact, consistent with an "acclimation effect", ethno-national biases appear to be amplified by the experience of sitting on an apex court in a deeply divided society.

These findings cut against a strategic explanation. As we noted earlier, BosniaHerzegovina's fragmented and decentralized system insulates the Court from direct court curbing. Thus, the apparent influence of ethno-national affiliation is probably not a function of a strategic response to direct threats against the Court as an institution. To be sure, we cannot completely dismiss the explanation that the judges are strategically motivated by personal incentives or pressures to side with co-ethnics. However, the fact that the short-term appointed judges are no less prone to side with co-ethnic petitioners, even though they would have relatively greater careerist incentives to do so, strongly suggests that the observed patterns really do reflect sincere political preferences and/or inter-group biases. In other words, the problem appears to be a lack of impartiality (as opposed to independence).

Our findings also have some important implications for the study of courts more generally. Our analysis demonstrates that the attitudinal model can be modified and extended to study the influence of group-based identity politics on judicial behaviour. In many 
societies, this kind of politics is more salient than left-right ideological cleavages. Although we have not controlled for the full range of rival hypotheses that are relevant to the attitudinal model, our findings provide some preliminary support for the claim that ethno-nationalist attitudinal influences are distinct from - and perhaps more powerful than - left-right attitudinal influences. We hope that further studies will incorporate a similar approach in advancing the study of judicial behaviour in non-US contexts. Our findings also suggest that the phenomenon of acclimation effects, previously observed in the US, may be broadly generalizable to other contexts. And if this is so - if accumulated tenure tends to enhance attitudinal bias - longer judicial mandates may not be the optimal design choice for constitutional courts in divided societies.

Some might argue that the influence of ethno-national affiliation on judicial behaviour is really not such a grave problem. After all, the US Supreme Court enjoys a comparatively high degree of diffuse public support, despite the fact that its decision-making is popularly perceived to be influenced by the justices' personal ideology and values (Gibson \& Caldeira 2011). However, as Gibson and Caldeira observe, this popular perception of the US Supreme Court coexists with the view that the justices are nevertheless "principled" decision-makers and not mere "politicians in robes" (2011:214). Although there is yet to be any comparable empirical research on the legitimacy of the Constitutional Court of Bosnia-Herzegovina, the decision-making patterns we have observed here are arguably less compatible with diffuse public support, at least in a deeply divided and post-conflict society. The Court exists in a context very unlike the American one; there is no long-standing tradition of the rule of law and the legitimacy of the Constitution is itself widely contested along ethno-national lines. The negotiators of the Bosnian Constitution may well have anticipated (and even hoped) that the domestic judges would tend to represent their respective ethno-national blocs; the inclusion of international judges as a putative balancing force on the Court would seem to 
suggest as much. However, once it becomes apparent that one community's constitutional preferences tend to benefit from this arrangement, the notion that the international judges are somehow neutral is probably not much consolation to those on the losing side. It is perhaps not surprising then that the Court has had the significant compliance problems we have noted here. Such problems are not necessarily caused by a legitimacy deficit, but the perceived ethno-national partiality of the judges provides easy ammunition for those who would seek to shirk compliance with particular decisions or undermine the Court's authority more generally.

The question then is what, if anything, can be done to ameliorate this kind of problem. It is tempting, perhaps, to conclude that judicial impartiality in a deeply divided society is an absurd ideal. In such contexts, regardless of the appointment mechanism, judges are likely to be ethnically or ethno-nationally impartial for the simple reason that most people are ethnically or ethno-nationally impartial. Indeed, even an ostensibly apolitical appointment system can be captured by ethnic or ethno-national politics but there are some institutional reforms that might at least mitigate these hazards. Strict selection criteria for judicial office might limit the ability of political elites to pack a court with reliable allies. This does not guarantee that ethno-nationalist judges will not be appointed regardless, but it might help more impartial judges to win the selection contest more often. Reforms to legal education or judicial training might also be directed towards more integrated professional socialization in the hope that this would soften ethnocentric perspectives. Furthermore, as our findings here suggest, relatively shorter judicial mandates may actually be preferable to long-term tenure; if the influence of ethno-nationalism tends to grow with time, it may be better not to leave judges on the court for longer than is needed to secure their independence from the influence of post-appointment career pressures. Thus, in the case of the Bosnian Constitutional Court, appointments to the Court might be restricted to those who are already in their sixties, while 
still requiring retirement at age seventy. In this way, the problem of acclimation effects (if they do indeed exist) and the potential influence of post-tenure careerist pressures (if any) could both be addressed; judges would serve shorter-terms before retiring at an age after which they would have minimal post-appointment career prospects. Finally, the publication of dissents could be prohibited, as it is in several European constitutional courts (Kelemen 2013). Although this prohibition would inhibit the ability of people like us to study the judges' behaviour, a single institutional voice, uncomplicated by conspicuous ethno-national discord, might enhance a court's authority. These are just a few speculative proposals. Further research on the effects of judicial selection and tenure in other divided societies is needed to determine if these or other prescriptions are prudent and generalizable.

\section{References}

Abrams, David, Marianne Bertrand, \& Sendhil Mullainathan (2012) "Do Judges Vary in Their Treatment of Race?," 41(2) Journal of Legal Studies 347-383.

Amaral-Garcia, Sofia, Nuno Garoupa, \& Veronica Grembi (2009) "Judicial Independence and Party Politics in the Kelsenian Constitutional Courts: The Case of Portugal," 6(2) Journal of Empirical Legal Studies 381-404.

Bahtić-Kunrath, Birgit (2011) "Of Veto Players and Entity-Voting: Institutional Gridlock in the Bosnian Reform Process," 39(6) Nationalities Papers 899-923.

Banović, Damir, Sanela Muharemović, \& Dženana Kapo (2014) Strengthening the Capacity of the Constitutional Court of Bosnia and Herzegovina: How to Improve Decision Implementation and Enforcement? Sarajevo: Center for Political Studies. 
Berry, William D., Jacqueline HR DeMeritt, and Justin Esarey (2010) "Testing for Interaction in Binary Logit and Probit Models: Is A Product Term Essential?," 54(1) American Journal of Political Science 248-266.

Bieber, Florian. (2006) Post-War Bosnia: Ethnicity, Inequality and Public Sector Governance. Basingstoke: Palgrave Macmillan.

Boyd, Christina L., Lee Epstein, \& Andrew D. Martin (2010) "Untangling the Causal Effects of Sex on Judging," 54(2) American Journal of Political Science 389-411.

Boyea, Brent D. (2010) "Does Seniority Matter? The Conditional Influence of State Methods of Judicial Retention," 91(1) Social Science Quarterly 209-227.

Brace, Paul R., \& Melinda Gann Hall. (1997) "The Interplay of Preferences, Case Facts, Context, and Rules in the Politics of Judicial Choice," 59(4) The Journal of Politics 1206-1231.

Brambor, Thomas, William Roberts Clark, \& Matt Golder (2006) "Understanding Interaction Models: Improving Empirical Analyses," 14(1) Political Analysis 63-82.

Brinks, Daniel \& Abby Blass (2016) "Rethinking Judicial Empowerment: The New Foundations of Constitutional Justice", on file with authors.

Canes-Wrone, Brandice, Tom S. Clark, \& Jason P. Kelly. (2014) "Judicial Selection and Death Penalty Decisions," 108(1) American Political Science Review 23-39.

Caplan, Richard. "International Authority and State Building: The Case of Bosnia and Herzegovina," 10(1) Global Governance 53-65.

Cairns, Ed, Jared Kenworthy, Andrea Campbell, \& Miles Hewstone. (2006) "The Role of Ingroup Identification, Religious Group Membership and Intergroup Conflict in 
Moderating In-group and Out-group Affect," 45(4) British Journal of Social Psychology 701-716.

Chandrachud, Abhinav (2013) "Does Life Tenure Make Judges More Independent: A Comparative Study of Judicial Appointments in India," 28 Connecticut Journal of International Law 297.

Choi, Stephen J., Gaurang Mitu Gulati, \& Eric A. Posner (2011) "Professionals or Politicians: The Uncertain Empirical Case for an Elected Rather than Appointed Judiciary,” 26(2) Journal of Law, Economics and Organization 290-336.

Choudhry, Sujit \& Richard Stacey (2012) “Independent or Dependent? Constitutional Courts in Divided Societies," in Harvey, C. \& A. Schwartz, eds. Rights in Divided Societies. Oxford: Hart Publishing.

Choudhry, Sujit, ed. (2008) Constitutional Design for Divided Societies: Integration or Accommodation? Oxford: Oxford University Press.

Collins, Paul (2008) "The Consistency of Judicial Choice," 70(3) The Journal of Politics 861873.

Elkins, Zachary, Tom Ginsburg, \& James Melton (2009) The Endurance of National Constitutions. Cambridge: Cambridge University Press.

Epstein, Lee, Jack Knight, \& Olga Shvetsova (2001) "The Role of Constitutional Courts in the Establishment and Maintenance of Democratic Systems of Government," 35(1) Law and Society Review 117-164.

Epstein, Lee, Andrew D. Martin, Kevin M. Quinn, \& Jeffrey A. Segal (2007) "Ideological Drift among Supreme Court Justices: Who, When, and How Important," 101(4) Northwestern University Law Review 1483-1541. 
Epstein, Lee, \& Tonja Jacobi (2010) "The Strategic Analysis of Judicial Decisions," 6 Annual Review of Law and Social Science 341-358.

Epstein, Lee, William M. Landes, \& Richard A. Posner (2013) The Behavior of Federal Judges: A Theoretical and Empirical Study of Rational Choice. Cambridge MA: Harvard University Press.

Everly, Rebecca (2008) "Assessing the accountability of the High Representative," in Haynes, D.F. ed., Deconstructing the Reconstruction: Human Rights and Rule of Law in Postwar Bosnia and Herzegovina. Aldershot: Ashgate Publishing.

EU Delegation to Bosnia and Herzegovina, "Flash Report: Non-execution of the BiH Constitutional Court Decisions", 23 April 2015.

Feldman, David (2011) "The Independence of International Judges in National Courts: Lessons from Bosnia and Herzegovina," in Shetreet, S. \& C. Forsyth eds., The Culture of Judicial Independence: Conceptual Foundations and Practical Challenges. Leiden: Martinus Nijhoff/Brill.

Feldman, David (2005) "Renaming Cities in Bosnia and Herzegovina," 3(4) International Journal of Constitutional Law 649-662.

Ferejohn, John (2002) "Judicializing Politics, Politicizing Law," 65 Law \& Contemporary Problems 41-68.

Garoupa, Nuno, \& Tom Ginsburg (2011) "Building Reputation in Constitutional Courts: Political and Judicial Audiences," 28 Arizona Journal of International \& Comparative Law 539-568.

Garoupa, Nuno, Fernando Gomez-Pomar, \& Veronica Grembi (2013) "Judging Under Political Pressure: An Empirical Analysis of Constitutional Review Voting in the 
Spanish Constitutional Court," 29(3) Journal of Law, Economics, and Organization $513-534$.

Gibson, James L., \& Gregory A. Caldeira. (2011) "Has Legal Realism Damaged the Legitimacy of the US Supreme Court?," 45(1) Law \& Society Review 195-219.

Ginsburg, Tom (2003) Judicial Review in New Democracies: Constitutional Courts in Asian Cases. Cambridge: Cambridge University Press.

Ginsburg, Tom (2012) "Courts and New Democracies: Recent Works," 37(3) Law \& Social Inquiry 720-742.

Ginsburg, Tom \& Nuno Garoupa (2009) "Guarding the Guardians: Judicial Councils and Judicial Independence," 57 American Journal of Comparative Law 201-232.

Glaeser, Edward L., \& Bruce Sacerdote (2003) "Sentencing in Homicide Cases and the Roles of Vengeance," 32 Journal of Legal Studies 363-382.

Greiner, D. James, \& Donald B. Rubin (2011) "Causal Effects of Perceived Immutable Characteristics," 93(3) Review of Economics and Statistics 775-785.

Hagle, Timothy (1993) “"Freshman Effects’ for Supreme Court Justices," 37(4) American Journal of Political Science 1142-1157.

Haggard, Stephan, \& Lydia Tiede (2014) "The Rule of Law in Post-Conflict Settings: The Empirical Record," 58(2) International Studies Quarterly 405-417.

Hamilton, Alexander (2009) "Federalist No.78" in Shapiro, I. ed. The Federalist Papers, New Haven: Yale University Press.

Hayo, Bernd, \& Stefan Voigt (2007) "Explaining de facto Judicial Independence," 27(3) International Review of Law \& Economics 269-290. 
Helmke, Gretchen, \& Frances Rosenbluth (2009) "Regimes and the Rule of Law: Judicial Independence in Comparative Perspective," 12 Annual Review of Political Science 345-366.

Herron, Erik S., \& Kirk A. Randazzo (2003) "The Relationship between Independence and Judicial Review in Post-Communist Courts," 65(2) Journal of Politics 422-438.

Hettinger, Virginia A., Stefanie A. Lindquist, and Wendy L. Martinek (2003) "Acclimation Effects and Separate Opinion Writing in the US Courts of Appeals," 84(4) Social Science Quarterly 792-810.

Hirschl, Ran. (2014) Comparative Matters: The Renaissance of Comparative Constitutional Law. Oxford: Oxford University Press.

Hönnige, Christoph (2009) "The Electoral Connection: How the Pivotal Judge affects Oppositional Success at European Constitutional Courts," 35(5) West European Politics 963-984.

Horowitz, Donald (2006) "Constitutional Courts: A Primer for Decision Makers," 17(4) Journal of Democracy 125-137.

Horowitz, Donald L. (1985) Ethnic Groups in Conflict. Berkeley: University of California Press.

Hurwitz, Mark S., and Oseph V. Stefko (2004) "Acclimation and Attitudes: 'Newcomer' Justices and Precedent Conformance on the Supreme Court," 57(1) Political Research Quarterly 121-129.

International Bar Association (1982) Minimum Standards of Judicial Independence. New Delhi: IBA. 
Issacharoff, Samuel (2015) Fragile Democracies: Contested Power in the Era of Constitutional Courts. Cambridge: Cambridge University Press.

Jackson, Vicki (2007) "Packages of Judicial Independence: The Selection and Tenure of Article III Judges," 95(4) Georgetown University Law Journal 965-1008.

Jusic, Tarik, \& Nidžara Ahmetašević (2013) "Media Reforms through Intervention: International Media Assistance in Bosnia and Herzegovina," 3 ANALITIKA Center for Social Research Working Papers 8-70.

Kaheny, Erin B., Susan Brodie Haire, \& Sara C. Benesh (2008) "Change over Tenure: Voting, Variance, and Decision Making on the US Courts of Appeal," 52(3) American Journal of Political Science 490-503.

Kapiszewski, Diana, Gordon Silverstein, \& Robert A. Kagan (2013) Consequential Courts: Judicial Roles in Global Perspective. Cambridge: Cambridge University Press.

Karlan, Pamela S. (1998) "Two Concepts of Judicial Independence," 72 Southern California Law Review 72 (1998): 535-558.

Keil, Soren (2013) Multinational Federalism in Bosnia and Herzegovina. Farnham: Ashgate Publishing Ltd.

Kelemen, Katalin (2013) "Dissenting Opinions in Constitutional Courts," 14(8) German Law Journal 1345-1371.

Kennedy, James \& Liliana Riga (2013) “A Liberal Route from Homogeneity?: US Policymakers and the Liberalization of Ethnic Nationalists in Bosnia's Dayton Accords," 19(2) Nationalism and Ethnic Politics 163-186.

Kulenović, Nedim (2016) “The Bosnian Constitutional Court as a Policy Maker", on file with author. 
La Porta, Rafael, Florencio Lopez-de-Silanes, Cristian Pop-Eleches, \& Andrei Shleifer. (2004) "Judicial Checks and Balances," 112(2) Journal of Political Economy 445-470.

Lake, David A., \& Donald Rothchild (1996) "Containing Fear: The Origins and Management of Ethnic Conflict," 21(2) International Security 41-75.

Landau, David (201) "Political Institutions and Judicial Role in Comparative Constitutional Law," 51 Harvard International Law Journal 51 319-377.

Luther, Kurt Richard (1999) “A Framework for the Comparative Analysis of Political Parties and Party Systems in Consociational Democracy", in Deschouwer, K. \& K. R. Luther, eds. Party Elites in Divided Societies. London: Routledge.

Lijphart, Arend (1977) Democracy in Plural Societies: A Comparative Exploration. New Haven: Yale University Press.

Marcellesi, Alexandre (2013) "Is Race a Cause?" 80(5) Philosophy of Science 650-659.

Marko, Joseph (2005) "Post-conflict Reconstruction through State-and Nation-building: The Case of Bosnia and Herzegovina," European Diversity and Autonomy Paper 4/2005, at $\quad$ www.eurac.edu/en/research/autonomies/minrig/publications/Pages/EuropeanAutonomy-and-Diversity-Papers-\%28EDAP\%29.aspx.

McCrudden, Christopher, \& Brendan O'Leary (2013) Courts and Consociations: Human Rights Versus Power-Sharing. Oxford: Oxford University Press.

McGarry, John, \& Brendan O'Leary (2007) "Iraq's Constitution of 2005: Liberal Consociation as Political Prescription," 5(4) International Journal of Constitutional Law 670-698. 
Melton, James \& Tom Ginsburg (2014) “Does De Jure Judicial Independence Really Matter? A Reevaluation of Explanations for Judicial Independence," 2(2) Journal of Law and Courts 187-217.

Moore, Margaret (2001) The Ethics of Nationalism. Oxford: Oxford University Press.

North, Douglass C., \& Barry R. Weingast (1989) "Constitutions and Commitment: The Evolution of Institutions Governing Public Choice in Seventeenth-century England," 49(4) The Journal of Economic History 803-832.

Office of Democracy and Governance (2002) Guidance for Promoting Judicial Independence and Impartiality. Washington, DC: United States Agency for International Development.

Prism Research (2013) Public Opinion Poll. Sarajevo: United Nations Resident Coordinator Office in Bosnia and Herzegovina.

Radić-Dragić, Renata (2012) "Politički uticaj na izbor sudija ustavnih sudova: prekršaji sudske neovisnosti", in Human Rights and Judiciary in Bosnia and Herzegovina: A Report on Implementation of the Recommendations for Justice Sector in Bosnia and Herzegovina from the Universal Periodic Review of the UN Human Rights Council. Sarajevo: BiH Justice Network / USAID.

Reddick, Malia (2001) "Merit Selection: A Review of the Social Scientific Literature," 106(4) Dickson Law Review 729-745.

Sadurski, Wojciech (2014) Rights Before Courts: A Study of Constitutional Courts in Postcommunist States of Central and Eastern Europe. London: Springer.

Schor, Miguel (2009) "An Essay on the Emergence of Constitutional Courts: The Cases of Mexico and Colombia," 16(1) Indiana Journal of Global Legal Studies 173-194. 
Segal, Jeffrey A., \& Harold J. Spaeth (2002) The Supreme Court and the Attitudinal Model Revisited. Cambridge: Cambridge University Press.

Sen, Maya, \& Omar Wasow (2016) "Race as a 'Bundle of Sticks': Designs that Estimate Effects of Seemingly Immutable Characteristics," 19 Annual Review of Political Science 499-522.

Shepherd, Joanna M. (2009) "The Influence of Retention Politics on Judges' Voting," 38(1) The Journal of Legal Studies 169-206.

Smithey, Shannon Ishiyama, \& John Ishiyama (2002) "Judicial Activism in Post-Communist Politics." 36(4) Law \& Society Review 719-742.

Stone, Alec (1990) "The Birth and Development of Abstract Review: Constitutional Courts and Policymaking in Western Europe," 19(1) Policy Studies Journal 81-95.

Sunstein, Cass R., David Schkade, and Lisa Michelle Ellman (2004) "Ideological Voting on Federal Courts of appeals: A Preliminary Investigation," Virginia Law Review 301354.

Tajfel, Henri (1974) "Social Identity and Intergroup Behaviour" 13(2) Social Science Information/Sur Les Sciences Sociales 65-93.

Tajfel, Henri, Michael G. Billig, Robert P. Bundy, \& Claude Flament (1971) "Social Categorization and Intergroup Behavior,” 1 European Journal of Social Psychology $149-178$. 
Tajfel, Henri, \& John C. Turner (1979) "An Integrative Theory of Intergroup Conflict," in Austin, W. G. \& S. Worchel eds., The Social Psychology of Intergroup Relations. Monterey, CA: Brooks

Volcansek, Mary (2007) "Appointing Judges the European Way," 34(1) Fordham Urban Law Journal 363-385.

Tiede, Lydia (2006) "Judicial Independence: Often Cited, Rarely Understood," 15 Journal of Contemporary Legal Issues 129-161.

Tsebelis, George (2002) Veto Players: How Political Institutions Work. Princeton: Princeton University Press.

Wood, Sandra L., Linda Camp Keith, Drew Noble Lanier, \& Ayo Ogundele (1998) ““Acclimation Effects’ for Supreme Court Justices: A Cross-Validation, 1888-1940," 42(2) American Journal of Political Science 690-697.

Zorn, Christopher (2006) "Comparing GEE and Robust Standard Errors for Conditionally Dependent Data," 59(3) Political Research Quarterly 329-341.

Alex Schwartz is Lecturer in Law at Queen's University Belfast and an Associate of the Political Settlements Research Programme (www.politicalsettlements.org/about/). His research focuses on courts and judicial behaviour in divided societies, as well as powersharing and the accommodation of national pluralism. He is co-editor (with Colin Harvey) of Rights and Divided Societies (Oxford: Hart 2012).

Melanie Janelle Murchison is an Associate Lecturer in the Department of Sociology and the Legal Studies Program at the University of Wisconsin - Madison. She is also affiliated with 
the political science department at UW - Madison and teaches courses on comparative constitutional law, law and politics and legal systems. Her research focuses on the behaviour of Supreme Courts and the influences on their decision making processes. 